\title{
P2X4 Receptor Reporter Mice: Sparse Brain Expression and Feeding-Related Presynaptic Facilitation in the Arcuate Nucleus
}

\author{
Ji Xu, ${ }^{1}$ Alexander M. Bernstein, ${ }^{2 *} \oplus^{\oplus}$ Angela Wong, ${ }^{2 *}{ }^{\oplus}$ Xiao-Hong Lu, ${ }^{4}$ Sheraz Khoja, ${ }^{6}$ X. William Yang, ${ }^{4,5}$ \\ ๑Daryl L. Davies, ${ }^{3}$-Paul Micevych, ${ }^{2}$ (Dichael V. Sofroniew, ${ }^{2}$ and Baljit S. Khakh ${ }^{1,2}$ \\ Departments of ${ }^{1}$ Physiology and ${ }^{2}$ Neurobiology, David Geffen School of Medicine, University of California-Los Angeles, Los Angeles, California 90095, \\ ${ }^{3}$ Titus Family Department of Clinical Pharmacy, School of Pharmacy, University of Southern California, Los Angeles, California 90089, ${ }^{4}$ Center for \\ Neurobehavioral Genetics, Semel Institute for Neuroscience and Human Behavior, University of California-Los Angeles, Los Angeles, California 90095, \\ ${ }_{5}^{5}$ Department of Psychiatry and Biobehavioral Sciences, David Geffen School of Medicine, University of California-Los Angeles, Los Angeles, \\ California 90095, and ${ }^{6}$ Department of Pharmacology and Pharmaceutical Sciences, University of Southern California, Los Angeles, California 90089
}

P2X4 receptors are ATP-gated cation channels that are widely expressed in the nervous system. To identify P2X4 receptor-expressing cells, we generated BAC transgenic mice expressing tdTomato under the control of the P2X4 receptor gene (P2rx4). We found sparse populations of tdTomato-positive neurons in most brain areas with patterns that matched P2X4 mRNA distribution. tdTomato expression within microglia was low but was increased by an experimental manipulation that triggered microglial activation. We found surprisingly high tdTomato expression in the hypothalamic arcuate nucleus (Arc) (i.e., within parts of the neural circuitry controlling feeding). Immunohistochemistry and genetic crosses of P2rx4 tdTomato mice with cell-specific GFP reporter lines showed that the tdTomato-expressing cells were mainly AgRP-NPY neurons and tanycytes. There was no electrophysiological evidence for functional expression of P2X4 receptors on AgRP-NPY neuron somata, but instead, we found clear evidence for functional presynaptic P2X4 receptor-mediated responses in terminals of AgRP-NPY neurons onto two of their postsynaptic targets (Arc POMC and paraventricular nucleus neurons), where ATP dramatically facilitated GABA release. The presynaptic responses onto POMC neurons, and the expression of tdTomato in AgRP-NPY neurons and tanycytes, were significantly decreased by food deprivation in male mice in a manner that was partially reversed by the satiety-related peptide leptin. Overall, we provide well-characterized tdTomato reporter mice to study P2X4expressing cells in the brain, new insights on feeding-related regulation of presynaptic $\mathrm{P} 2 \mathrm{X} 4$ receptor responses, and the rationale to explore extracellular ATP signaling in the control of feeding behaviors.

Key words: arcuate; ATP; ion channel; mouse model; P2X; receptor

Significance Statement

Cells expressing ATP-gated P2X4 receptors have proven problematic to identify and study in brain slice preparations because P2X4 expression is sparse. To address this limitation, we generated and characterized BAC transgenic P2rx4 tdTomato reporter mice. We report the distribution of tdTomato-expressing cells throughout the brain and particularly strong expression in the hypothalamic arcuate nucleus. Together, our studies provide a new, well-characterized tool with which to study P2X4 receptorexpressing cells. The electrophysiological studies enabled by this mouse suggest previously unanticipated roles for ATP and P2X4 receptors in the neural circuitry controlling feeding.

\section{Introduction}

Extracellular ATP functions as a signaling molecule in the nervous system by activating plasma membrane $\mathrm{P} 2 \mathrm{X}$ and $\mathrm{P} 2 \mathrm{Y}$ receptors

Received May 7, 2016; revised June 17, 2016; accepted June 20, 2016.

Author contributions: J.X., P.M., and B.S.K. designed research; J.X., A.M.B., A.W., and B.S.K. performed research; X.-H.L., S.K., X.W.Y., D.L.D., P.M., and M.V.S. contributed unpublished reagents/analytic tools; J.X. and B.S.K. analyzed data; J.X. and B.S.K. wrote the paper.
(Burnstock, 1972; Khakh and North, 2006). P2X receptors are ATPgated cation channels comprising seven subunits (P2X1-P2X7), six homomeric receptors, and several heteromeric assemblies (Khakh et
This work was supported by National Institutes of Health Grant NS073980, University of California-Los Angeles unrestricted funds, and in part by Grant NS060677 to B.S.K. The breeding of the P2X4 knock-out mice was supported by The National Institute of Alcohol Abuse and Alcoholism Grant AA022448 to D.L.D. The in vivo feeding experiments were supported by The National Institute of Drug Abuse Grant DA013185 to P.M. X.W.Y. and 
al., 2001; North, 2002). We focused on P2X4, which was cloned 20 years ago (Bo et al., 1995; Buell et al., 1996; Séguéla et al., 1996; Soto et al., 1996; Wang et al., 1996). Important progress has been made in understanding how P2X4 receptors work (Gonzales et al., 2009; Kawate et al., 2009; Coddou et al., 2011; Hattori and Gouaux, 2012; Jiang et al., 2013; Samways et al., 2014; Habermacher et al., 2016), but less is known about their expression and functions in the brain.

P2X4 receptors are expressed on the cell surface and also within acidic intracellular organelles (Bobanović et al., 2002; Royle et al., 2002, 2005; Bowler et al., 2003; Royle and MurrellLagnado, 2003; Qureshi et al., 2007; Murrell-Lagnado and Qureshi, 2008; Stokes and Surprenant, 2009; Toulme et al., 2010; Miklavc et al., 2011). Important roles for P2X4 receptors are emerging in a variety of pathophysiological processes. For example, $\mathrm{P} 2 \mathrm{X} 4$ receptors are upregulated in microglia following neuropathic pain and epilepsy (Tsuda et al., 2003; Coull et al., 2005; Ulmann et al., 2013). They are also implicated in inflammatory pain (Ulmann et al., 2010), lung surfactant secretion (Miklavc et al., 2011), alcohol intake (Wyatt et al., 2014), alcohol preference (Ostrovskaya et al., 2011; Yardley et al., 2012), morphineinduced hyperalgesia (Ferrini et al., 2013), cardiac function (Yang et al., 2004), and neurodevelopmental disorders (Bortolato et al., 2013; Wyatt et al., 2013). These diverse roles for P2X4 receptors likely reflect their distribution in several brain regions and other organs, which was first reported by in situ hybridization studies (Buell et al., 1996). However, identifying native P2X4 receptor responses within intact preparations, such as brain slices, has proven extremely challenging. First, there are no selective $\mathrm{P} 2 \mathrm{X} 4$ receptor agonists or antagonists for use in rodents, making it difficult to pinpoint $\mathrm{P} 2 \mathrm{X} 4$ receptor-expressing cells based on function (Ase et al., 2015). Moreover, although ivermectin is a potent allosteric regulator of $\mathrm{P} 2 \mathrm{X} 4$ receptors (Khakh et al., 1999), it has actions at other receptors (Zemková et al., 2014) that limit its usefulness as a selective P2X4 receptor probe in multicellular preparations. Second, despite $>15$ years of work, all of the available and reported $\mathrm{P} 2 \mathrm{X} 4$ receptor antibodies target intracellular epitopes. They are also of questionable specificity; they are thus of little or no utility in live tissues. Third, brain cells expressing P2X4 receptors are expected to be sparse, making it problematic to achieve targeted electrophysiological recordings (Buell et al., 1996; Collo et al., 1996; Lê et al., 1998; Lein et al., 2007). These issues have markedly limited exploration of P2X4 receptor function in brain slices.

We report the generation and characterization of $P 2 r \times 4$ BAC transgenic reporter mice (Yang and Gong, 2005) expressing the orange/red fluorescent protein tdTomato (Shaner et al., 2005) under the control of the P2X4 locus. We describe the distribution of tdTomato-expressing cells throughout the brain, which matches P2X4 mRNA (Buell et al., 1996; Collo et al., 1996; Lein et al., 2007). The use of P2rx4 tdTomato mice revealed strong ex-

X.-H.L. were supported by National Institute on Drug Abuse National Institutes of Health P50 DA005010. X.-H.L. was also supported by a National Alliance for Research on Schizophrenia and Depression Young Investigator Award. The M.V.S. laboratory was supported by National Institutes of Health Grant NSO84030.

*Equally contributing second authors.

The authors declare no competing financial interests.

Correspondence should be addressed to Dr. Baljit S. Khakh, Department of Physiology, David Geffen School of Medicine, University of California-Los Angeles, 10833 Le Conte Avenue, 53-263 CHS, Los Angeles, CA 90095-1751. E-mail: bkhakh@mednet.ucla.edu.

X.-H. Lu's present address: Department of Pharmacology, Toxicology and Neuroscience, Louisiana State University Health Sciences Center-Shreveport, 1501 Kings Highway, Shreveport, LA 71130_3932.

DOI:10.1523/JNEUROSCI.1496-16.2016

Copyright $\odot 2016$ the authors $\quad 0270-6474 / 16 / 368903-19 \$ 15.00 / 0$ pression in the hypothalamic arcuate nucleus (Arc), an area where P2X responses had not been described in detail (Stojilkovic, 2009). Immunohistochemistry (IHC) and breeding of P2rx4 tdTomato mice with cell-specific GFP reporter lines revealed that $\mathrm{P} 2 \mathrm{X} 4$ receptors were expressed in the AgRP-NPY neurons. Electrophysiological evaluations showed that $\mathrm{P} 2 \mathrm{X} 4$ receptors mediated presynaptic facilitation of GABA release onto POMC neurons. These responses were strongly regulated by food deprivation and leptin, which engage Arc satiety-related signaling. Together, our studies provide a new well-characterized tool with which to study P2X4 receptor-expressing cells and suggest unanticipated roles for ATP signaling in the neural circuitry controlling feeding.

\section{Materials and Methods}

All animal experiments were conducted in accordance with the National Institute of Health Guide for the care and use of laboratory animals and were approved by the Chancellor's Animal Research Committee at the University of California-Los Angeles.

Generation of P2rx4 tdTomato BAC transgenic mice. A $191 \mathrm{~kb}$ mouse bacterial artificial chromosome (BAC \#RP23-448O6) containing the 21 $\mathrm{kb}$ P2X ligand-gated ion channel 4 (P2X4) coding region, $\sim 100 \mathrm{~kb} 5^{\prime}$ flanking region, and $\sim 70 \mathrm{~kb} 3^{\prime}$ flanking region was identified through a database search and obtained from the BACPAC Resource Center (Oakland Children's Hospital, Oakland, CA). The cDNA of the orange/red fluorescent protein, tdTomato with a PolyA sequence, was inserted into exon 1 of the P2rx4 gene to replace the endogenous initiation of translation codon, according to an established protocol (Yang and Gong, 2005). The construction of the recombination cassette, subcloning into a shuttle vector ( $\mathrm{pLD} 53 . \mathrm{SC}-\mathrm{AB}$ ), homologous $\mathrm{BAC}$ recombination, and purification of intact BAC DNA for pronuclear injections were all done following described procedures (Yang and Gong, 2005). A $10 \mu \mathrm{l}$ sample of the fully modified and verified BAC DNA was analyzed by pulse-field gel electrophoresis to confirm BAC band integrity, quality, and size. Circular BAC DNA concentration was measured using a Nanodrop spectrophotometer before being diluted to a final concentration of $\sim 2 \mathrm{ng} / \mu \mathrm{l}$ by the transgenic core facility (University of California-Los Angeles) and used for embryo injections. The incorporation of the transgene into the mouse genome was identified through PCR. The genotyping primers for the transgene were as follows: $5^{\prime}$-AGT CAG GGG ACT GAC TCT TCA GCA CTC-3' and 5'-TCC TCG CCC TTG CTC ACC ATG G-3'. The P2rxy tdTomato transgenic mouse line will be available from The Jackson Laboratory (JAX\#029332).

Wild-type and transgenic mice. C57BL/6J-Tg(POMC-EGFP)1Low/J and B6.FVB-Tg(Npy-hrGFP)1Lowl/J mice (JAX\#009593 and JAX\# 006417, respectively) were acquired from The Jackson Laboratory. Transgenic mice, including P2rx4 tdTomato mice, were maintained by breeding with C57BL/6N mice (from Taconic), and hemizygous transgenic mice were used for experiments. All the mice were housed with food and water available ad libitum in a light-controlled environment. In a specific set of experiments, food deprivation lasted for $24 \mathrm{~h}$, starting at 09:00. Both male and female mice between 4 and 8 weeks old were used for electrophysiology and immunohistochemistry studies. Eight-weekold male mice were used for feeding studies. P2X4 knock-out mice were made by Francois Rassendren (Sim et al., 2006; Ulmann et al., 2008) and provided to us from a colony maintained at the University of Southern California in the D.L.D. laboratory.

Hippocampal lipopolysaccharide (LPS) injections. All surgical procedures were conducted under general anesthesia using continuous isoflurane (induction at $5 \%$, maintenance at $1-2.5 \% \mathrm{v} / \mathrm{v}$ ). Depth of anesthesia was monitored continuously and adjusted when necessary. After induction of anesthesia, the mice were fitted into a stereotaxic frame, with their heads secured by blunt ear bars and their noses placed into an anesthesia and ventilation system (David Kopf Instruments). Mice were administered buprenorphine $(0.1 \mathrm{mg} / \mathrm{kg}$; Buprenex $)$ subcutaneously before surgery. The surgical incision site was then cleaned three times with $10 \%$ povidone iodine and $70 \%$ ethanol. Skin incisions were made, followed by craniotomies of $2-3 \mathrm{~mm}$ in diameter above the left parietal cortex using a small steel burr (Fine Science Tools) powered by a high-speed drill 
(K.1070; Foredom). Saline (0.9\%) was applied onto the skull to reduce heating caused by drilling. In this study, $1 \mu \mathrm{l}$ injections of $4 \mu \mathrm{g} / \mu \mathrm{l}$ LPS from Escherichia coli 0127:B8 (Sigma, L5024) were delivered over a 2 min period into each hippocampus. Stereotaxic coordinates from bregma were $2 \mathrm{~mm}$ posterior to bregma, $1.5 \mathrm{~mm}$ lateral to midline, and $1.6 \mathrm{~mm}$ from the pial surface. After surgery, animals were allowed to recover overnight in cages placed partially on a low-voltage heating pad. Buprenorphine was administered two times per day for up to $2 \mathrm{~d}$ after surgery. In addition, trimethoprim sulfamethoxazole (40 and $200 \mathrm{mg}$, respectively, per $500 \mathrm{ml}$ water) was dispensed in the drinking water. This procedure did not adversely affect animal survival. The mice injected with saline or LPS were killed $3 \mathrm{~d}$ after injection, the brains removed and studied by immunohistochemistry.

Histology and immunohistochemistry (IHC). For transcardial perfusion, mice were killed with pentobarbitol (i.p.). Once all reflexes subsided, the abdominal cavity was opened. Heparin $(0.1 \mathrm{ml})$ was injected into the heart to prevent the blood from clotting. The animal was perfused with $50 \mathrm{ml}$ ice-cold $0.1 \mathrm{M}$ PBS followed by $50 \mathrm{ml} 10 \%$ buffered formalin (Fisher). After gentle removal from the skull, the brain was postfixed in $10 \%$ buffered formalin overnight. The tissue was cryoprotected in buffered 30\% sucrose solution the following day for at least $2 \mathrm{~d}$ at $4^{\circ} \mathrm{C}$ until use. The $40 \mu \mathrm{m}$ coronal frozen sections were prepared using a cryostat microtome (Leica) and processed for immunohistochemistry. To stain tdTomato for brightfield microscopy, sections were washed in $0.1 \mathrm{M}$ PBS and treated with $\mathrm{H}_{2} \mathrm{O}_{2}(1 \%)$ for 20 min to block endogenous peroxidase activity. The sections were incubated with $5 \%$ normal goat serum (NGS) and $0.5 \%$ Trition-X 100 in $0.1 \mathrm{M} \mathrm{PBS}$ at room temperature for $60 \mathrm{~min}$. Sections were then incubated with anti tdTomato antibody (1:2500; Rockland) in $0.1 \mathrm{M}$ PBS for $24 \mathrm{~h}$ at room temperature. After three 10 min washes in $0.1 \mathrm{M}$ PBS, the sections were incubated with biotinylated goat anti-rabbit antibody (1:400; Vector ABC Elite) in $0.1 \mathrm{M}$ PBS with $5 \%$ NGS for $2 \mathrm{~h}$ at room temperature. After another three $10 \mathrm{~min}$ washes in $0.1 \mathrm{M}$ PBS, the sections were incubated for $2 \mathrm{~h}$ in avidin-biotin complex (Vector ABC Elite) in $0.1 \mathrm{~m}$ PBS containing $0.2 \%$ Triton X-100. The staining was visualized by incubation with Vector SG peroxidase substrate (blue products) and $\mathrm{H}_{2} \mathrm{O}_{2}$ in $0.05 \mathrm{M}$ Tris buffer, $\mathrm{pH}$ 7.6. The brain sections were subsequently dehydrated and mounted with Eukitt (Calibrated Instruments).

For immunostaining for fluorescence microscopy, thin sections were washed 3 times in $0.1 \mathrm{~m}$ PBS for $10 \mathrm{~min}$ each, before being incubated in a blocking solution containing 5\% NGS in $0.1 \mathrm{~m}$ PBS with $0.5 \%$ Triton $\mathrm{X}-100$ for $1 \mathrm{~h}$ at room temperature on a shaker. Sections were then incubated in primary antibodies diluted in $0.1 \mathrm{M}$ PBS with $0.5 \%$ Triton X-100 overnight at $4^{\circ} \mathrm{C}$. The following primary antibodies were used: rabbit anti-RFP (1:200; Rockland), mouse anti$\mathrm{HuC} / \mathrm{HuD}$ (1:1000; Invitrogen), mouse anti-GFAP (1:1000; Millipore), chicken anti-vimentin (1:1000; Millipore), and chicken anti-GFP (1:1000; Abcam). The next day, the sections were washed 3 times in $0.1 \mathrm{M}$ PBS for $10 \mathrm{~min}$ each before incubation at room temperature for $2 \mathrm{~h}$ with secondary antibodies diluted in 5\% NGS in $0.1 \mathrm{M}$ PBS. The following Alexa-conjugated secondary antibodies were used: goat anti-rabbit 488 (1:500), goat anti-chicken 488 (1:500), goat anti-chicken 546 (1:500), goat anti-mouse 546 (1:500), and goat antirabbit 594 (1:500; all from Invitrogen). The sections were then rinsed 3 times in $0.1 \mathrm{M}$ PBS for 10 min each before being mounted on microscope slides. Fluorescence images were taken using UPlanSApo $20 \times 0.85 \mathrm{NA}$ and UPlanFL $40 \times 1.30 \mathrm{NA}$ oil-immersion objective lens and the FV300 Fluoview confocal laser-scanning microscope. We used the $488 \mathrm{~nm}$ line of an argon laser to excite Alexa-488, with the intensity adjusted to $0.5 \%-5 \%$ of the maximum output, which was 10 $\mathrm{mW}$. The emitted light pathway consisted of an emission high pass filter (505-525 nm) before the photomultiplier tube. Alexa-546 and Alexa-594 were excited by the $543 \mathrm{~nm}$ laser line of the $\mathrm{HeNeG}$ laser at $30 \%$ of the maximum output $(1 \mathrm{~mW})$. The emitted light pathway consisted of a dichroic mirror (SDM560) and a 560-600 nm emission filter. The acquired images were processed by ImageJ software. Colocalization of two proteins in a cell was defined by overlapping of green and red fluorescent signals from Alexa-conjugated secondary antibodies in a single cell. Cell numbers were counted manually.
Live fluorescence imaging. Brain slices used for fluorescence imaging were prepared exactly as described for electrophysiology (below). Fluorescence images of live brain slices from POMC GFP, NPY hrGFP, and P2rx4 tdTomato mice were taken using LUMPlanFL $40 \times 0.80$ NA waterimmersion objective lens and the FV300 Fluoview confocal laserscanning microscope. GFP was excited by the $488 \mathrm{~nm}$ line of an argon laser with the intensity adjusted to $0.5 \%-5 \%$ of the maximum output, which was $10 \mathrm{~mW}$. The emitted light pathway consisted of an emission high pass filter $(505-525 \mathrm{~nm})$ before the photomultiplier tube. tdTomato proteins were excited by the $543 \mathrm{~nm}$ laser line of the $\mathrm{HeNeG}$ laser at $30 \%$ of the maximum output $(1 \mathrm{~mW})$. The emitted light pathway consisted of a dichroic mirror (SDM560) and a 560-600 nm emission filter. Cells were selected from the Arc and were typically $20-40 \mu \mathrm{m}$ from the slice surface. Confocal images were taken at $1 \mu \mathrm{m}$ step size, and $20 z$-series images were $z$-projected and presented in the figures.

Voltage- and current-clamp electrophysiology. For brain slice preparation, mice were deeply anesthetized with isoflurane and decapitated. Coronal brain slices (300 $\mu \mathrm{m}$ thickness) were prepared in chilled cutting solution comprising the following (in $\mathrm{mM}$ ): 110 choline chloride, $2.5 \mathrm{KCl}$, $1.25 \mathrm{mM} \mathrm{NaH}_{2} \mathrm{PO}_{4}, 2 \mathrm{CaCl}_{2}, 7 \mathrm{MgSO}_{4}, 25$ D-glucose, $3.1 \mathrm{Na}$-pyruvate, and $11.6 \mathrm{Na} \mathrm{L}$-ascorbate, bubbled with $95 \% \mathrm{O}_{2} / 5 \% \mathrm{CO}_{2}$. During incubation, the slices were submerged at room temperature in aCSF comprising the following (in $\mathrm{mm}$ ): $119 \mathrm{NaCl}, 25 \mathrm{NaHCO}_{3}, 11 \mathrm{D}$-glucose, $2.5 \mathrm{KCl}, 1$ $\mathrm{MgCl}_{2}, 2 \mathrm{CaCl}_{2}$, and $1.25 \mathrm{NaH}_{2} \mathrm{PO}_{4}$, bubbled with $95 \% \mathrm{O}_{2} / 5 \% \mathrm{CO}_{2}$. Brain slices were incubated at $34^{\circ} \mathrm{C}$ for $30 \mathrm{~min}$ and then brought to room temperature until transfer to a recording chamber perfused with aCSF at a rate of $1-2 \mathrm{ml} / \mathrm{min}$ at room temperature $\left(20^{\circ} \mathrm{C}-22^{\circ} \mathrm{C}\right)$. The resistance of the pipettes was between 2 and $3 \mathrm{~m} \Omega$ when filled with a potassium chloride-based internal solution, comprising the following (in $\mathrm{mM}$ ): 130 $\mathrm{KCl}, 5 \mathrm{NaCl}, 10$ HEPES, 1 EGTA, $2 \mathrm{Na}$-ATP, $0.5 \mathrm{Na}_{2} \mathrm{GTP}$, and 5 sodium phosphocreatine, $\mathrm{pH} 7.35$. The cells were visualized with $900 \mathrm{~nm}$ infrared differential interference contrast optics (IR-DIC; Luigs \& Neumann Optical) on an upright microscope (Olympus BX51). Fluorescence excitation was achieved using an X-Cite 120 light source (Lumen Dynamics). The holding potential for voltage-clamp recordings was $-60 \mathrm{mV}$, and responses were digitized at $10 \mathrm{kHz}$. Only neurons with access resistances $<20 \mathrm{M} \Omega$ were used for recordings. Puffs of ATP were applied under visual control using a Picospritzer III (Parker Hannifin). In all cases, the same pipettes as those for electrophysiology recording were used for puffing and positioned $100 \mu \mathrm{m}$ away from the recorded neuron. Miniature IPSCs (mIPSCs) were recorded in the presence of $10 \mu \mathrm{M}$ CNQX, 50 $\mu \mathrm{M}$ cadmium chloride, and $0.5 \mu \mathrm{M}$ TTX. Evoked EPSCs (eEPSCs) were recorded with $1 \mathrm{~mm}$ QX-314 in recording pipettes and $10 \mu \mathrm{m}$ bicuculline in bath. Bipolar tungsten-stimulating electrodes were placed lateral to the arcuate nucleus to activate inputs to arcuate nucleus neurons. In all experiments, stimuli of $100 \mu$ s were used to elicit a synaptic response. Responses were evoked at a frequency of $0.05 \mathrm{~Hz}$ to record effects of drug perfusion. In most cases, recordings were initiated $5 \mathrm{~min}$ after whole-cell recordings were established.

In vivo delivery of ATP, leptin, and ghrelin and assessment of food intake. We used procedures based on published work (Wong et al., 2015; Yang et al., 2015). Mice (8- to 10-week old; male) were anesthetized with isoflurane (induction at $5 \%$, maintenance at $1 \%-2.5 \% \mathrm{v} / \mathrm{v}$ ) and placed on a stereotaxic apparatus. The skull was exposed via a small incision, and a small hole was drilled in the midline for guide cannula implantation. Bilateral 26 gauge stainless-steel cannulae ( $0.8 \mathrm{~mm}$ apart, Plastics One) were implanted using standard stereotaxic procedures (coordinates from bregma $-1.6 \mathrm{~mm}$, lateral $0.4 \mathrm{~mm}$, ventral $-5.0 \mathrm{~mm}$ from dura). Cannulae were secured to the skull with dental acrylic and stainless-steel bone screws. A 33 gauge stainless-steel obturator was inserted into the cannula to keep the guide cannula patent. For postoperative care, mice were injected intramuscularly with carprofen $(15 \mathrm{mg} / \mathrm{kg}$ ) to reduce pain for $2 \mathrm{~d}$ (once per day) and oral antibiotic (trimethoprim and sulfamethoxazole, $0.4 \mathrm{mg} / \mathrm{ml}$; Hi-Tech Pharmacal). Mice were returned to their home cages and singly housed, typically for at least 2 weeks to recover before drug delivery and feeding assays. The Arc was bilaterally microinfused with $500 \mathrm{nl}$ of vehicle control aCSF or ATP $(3 \mathrm{~mm})$ at a rate of $100 \mathrm{nl} / \mathrm{min}$ (total volume $0.5 \mu \mathrm{l} / \mathrm{side}$ ) using an infusion pump (Harvard Apparatus). Briefly injectors (33 gauge, Plastics One) were inserted and protruded $1 \mathrm{~mm}$ beyond the guide cannulae ( $6.0 \mathrm{~mm}$ from dura). The in- 
A

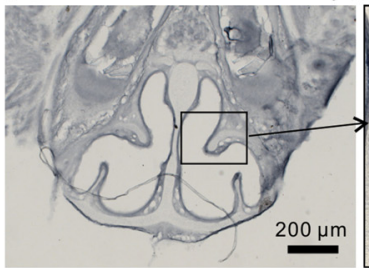

B $\operatorname{Brain}(n=5)$
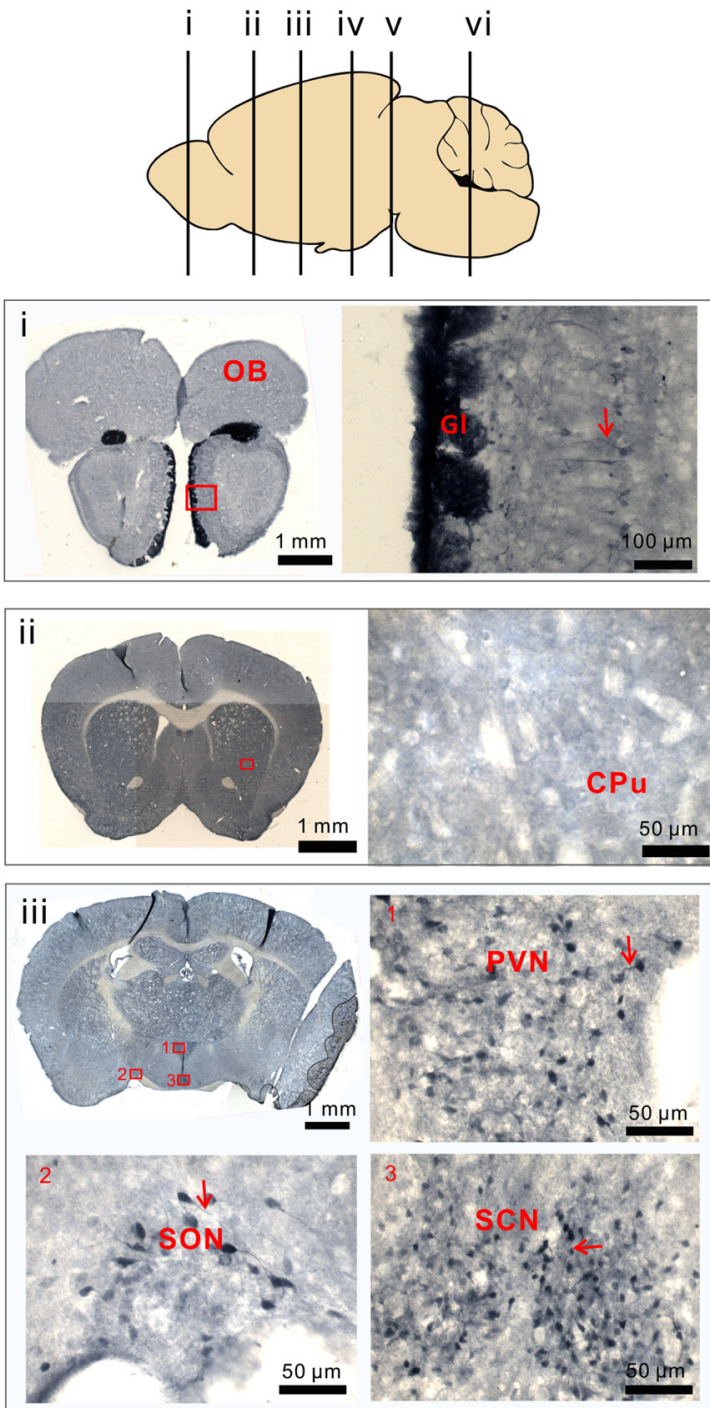

\section{Spinal $\operatorname{cord}(n=5)$}

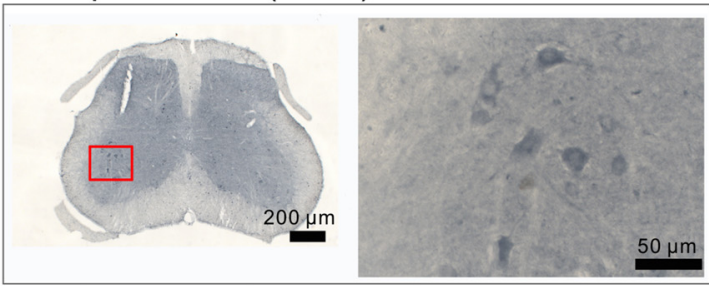

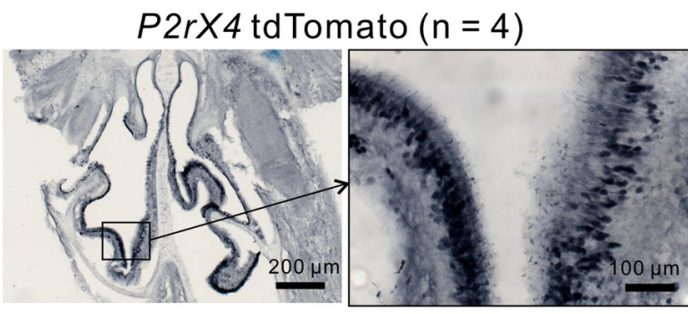
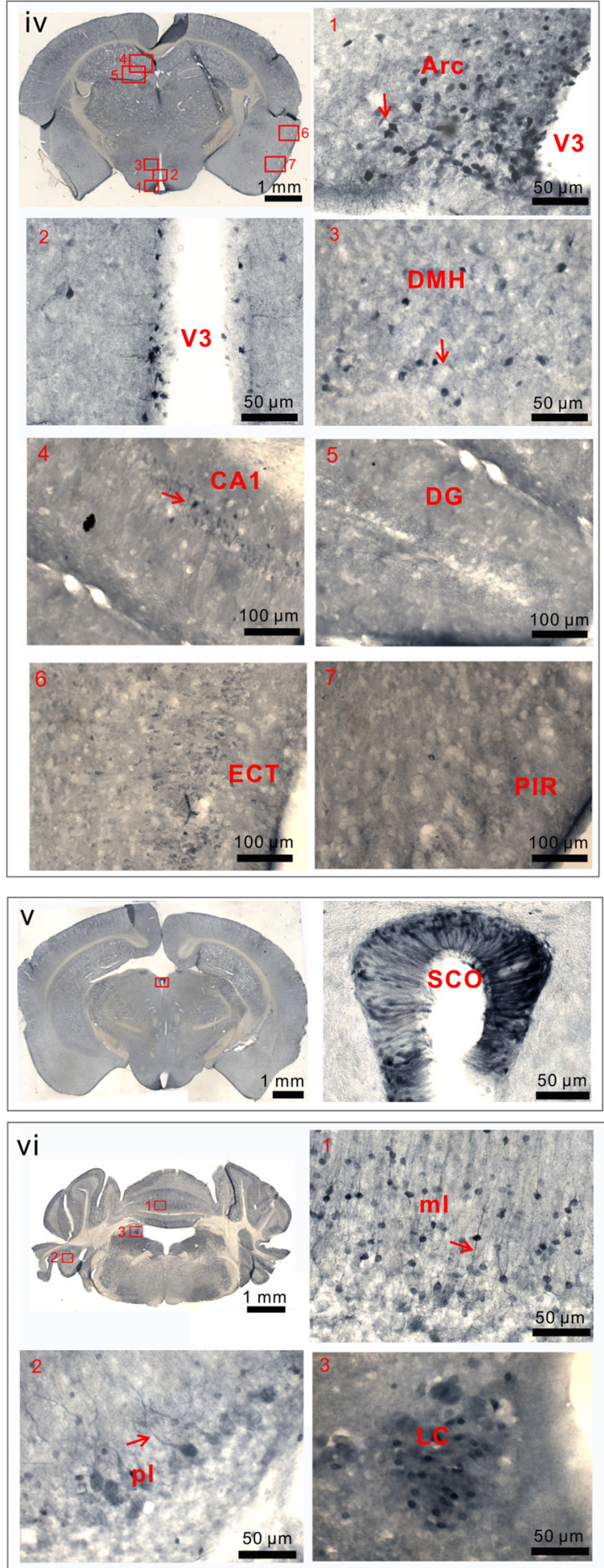

Figure 1. tdTomato expression in $P 2 r x 4$ tdTomato mice. $A$, Representative images of tdTomato IHC in olfactory tissue from wild-type and $P 2 r x 4$ tdTomato reporter mice. $\boldsymbol{B}$, Representative images of tdTomato-positive cells in the brain. Diagram represents the positions of coronal sections shown in Bi-Bvi. OB, Olfactory bulb; Gl, glomerular layer; $C P u$, corpus putamen; SON, supraoptic nucleus; SCN, suprachiasmatic nucleus; Arc, arcuate nucleus; V3, third ventricle; DMH, dorsal medial hypothalamus; DG, dentate gyrus; ECT, entorhinal cortex; PIR, piriform cortex; SC0, subcomissural organ; $\mathrm{ml}$, molecular layer; $\mathrm{pl}$, Purkinje layer; $\mathrm{LC}$, locus ceruleus. C, IHC images of tdTomato-positive cells in spinal cord. The neurons stained in the ventral horn were motor neurons. 
jectors were allowed to remain in place for $5 \mathrm{~min}$ after infusion to allow for diffusion away from the injector. Ghrelin was similarly applied at $0.7 \mathrm{~mm}$ (purchased from Sigma). Following microinjections, obturators were reinserted into guide cannulae, and mice were returned to their home cage. Food intake measurements began $1 \mathrm{~h}$ after microinjections at 09:00. Cannulae placements were confirmed histologically following the experiment. All the mice were housed with food and water available ad libitum on a $12 \mathrm{~h}$ light/ dark cycle, unless otherwise noted. For the experiments shown in Figure 9, food deprivation was for $24 \mathrm{~h}$, starting at 10:00. Leptin (Sigma) was dissolved in saline and injected intraperitoneally at $1 \mu \mathrm{g} / \mathrm{g}$ in a volume of $100 \mu \mathrm{l} 3 \mathrm{~h}$ before the mice were killed and used for slice preparation.

Data analyses. Synaptic currents were analyzed using MiniAnalysis program 6.0.7 (Synaptosoft) and Origin 8.5 (Origin Lab). Image analyses were performed using ImageJ version 1.30 (National Institutes of Health). For the experiments shown in Figure 9, the intensity of tdTomato immunofluorescence from neurons and tanycytes located $<200 \mu \mathrm{m}$ away from medial eminence was quantified by evaluating 10 images from a $z$-series at $1 \mu \mathrm{m}$ spacing. ROIs were selected on the somata of tdTomato-positive neurons and tanycytes. Average intensity of the tdTomato immunofluorescence in each ROI was measured using ImageJ and then subtracted by the background value. All statistical tests were run in GraphPad InStat 3 or Origin 9. The graphs were created in Origin 9 and assembled in CorelDraw12. Data are presented as mean \pm SEM. In some of the graphs, the bars representing the SEM are smaller than the symbols used to represent the mean. For each set of data to be compared, we determined within GraphPad Instat whether the data were normally distributed or not. If they were normally distributed, we used parametric tests. If the data were not normally distributed, we used nonparametric tests. Paired and unpaired Student's two-tailed $t$ tests (as appropriate) and two tailed Mann-Whitney tests were used for most statistical analyses with significance declared at $p<0.05$, but stated in each case with a precise $p$ value. When the $p$ value was $<0.001$, it is stated as $p<0.001$ to save space on the figure panels and tables. Throughout the manuscript, the results of statistical tests ( $p$ values and $n$ values) are reported in the figure panels. $N$ is defined as the numbers of cells and/or mice throughout on a case-by-case basis depending on the particular experiment.

Chemicals. All chemicals used were from VWR, Tocris Bioscience, or Sigma. In the text, the names of the chemicals abbreviated are adenosine 5'-O-(3-thio)triphosphate (ATP $\gamma S$ ), $\alpha, \beta$-methyleneadenosine 5 '-triphosphate $\left(\alpha, \beta\right.$-meATP) (4-benzoyl)benzoyl adenosine $5^{\prime}$-triphosphate (BzATP), APV, CNQX, GABA, pyridoxal-phosphate-6-azophenyl-2', $4^{\prime}$ disulfonic acid (PPADS), and TTX.

\section{Results}

Generation of transgenic BAC P2rxy tdTomato reporter mice Standard protocols were used for insertion of tdTomato at the $\mathrm{P} 2 \mathrm{X} 4$ receptor gene (P2rx4) start codon within the BAC DNA. Insertion was confirmed by PCR using flanking and insertspecific primers and with restriction analyses of the wild-type and modified BACs. The tdTomato sequence harbors a rare SbfI restriction site, and cutting with SbfI releases a diagnostic $8 \mathrm{~kb}$ band from the modified BAC, which was visualized by pulse-field gel electrophoresis. The modified P2rx4 tdTomato BAC clone was used for pronuclear injections after detailed characterization with PCR over regions of P2rx4 and tdTomato. Following injection of $\sim 200$ embryos, two potential founder lines of transgenic mice were generated. One of these resulted in germline transmission and was studied in detail. The insertion of tdTomato was confirmed by PCR of tail biopsy genomic DNA. The P2rx4 tdTomato mice were backcrossed with C57BL/6N mice for $>8$ generations. The mice reproduced, provided offspring in expected numbers, and displayed no obvious behavioral alterations, as expected with the BAC method that leaves the endogenous $\mathrm{P} 2 \mathrm{X} 4$ receptor locus intact (Yang et al., 1997).

We initially tested for tdTomato expression within transgenic mice using IHC with tdTomato antibodies. Past work shows that P2X4 mRNAs are strongly expressed in the olfactory epithelium
Table 1. Summary of tdTomato expression in P2rx4 tdTomato reporter mice in relation to P2X4 mRNA in past studies ${ }^{a}$

\begin{tabular}{|c|c|c|c|}
\hline & $\begin{array}{l}\text { P2rx4 tdTomato } \\
\text { (current study) }\end{array}$ & $\begin{array}{l}\text { P2X4 mRNA } \\
\text { Collo et al., } 1996\end{array}$ & $\begin{array}{l}\text { P2X4 mRNA Allen } \\
\text { Brain Atlas }\end{array}$ \\
\hline \multicolumn{4}{|l|}{ Olfactory bulb } \\
\hline Mitral cells & ++ & ++ & ++ \\
\hline Glomerular layer & ++++ & NA & +++ \\
\hline Anterior olfactory nucleus & + & + & + \\
\hline \multicolumn{4}{|l|}{ Cerebral cortex } \\
\hline Motor cortex & + & + & + \\
\hline Piriform cortex & ++ & ++ & ++ \\
\hline Frontal cortex & + & ++ & + \\
\hline \multicolumn{4}{|l|}{ Subcortical telencephalon } \\
\hline CA1-CA4 & + & ++ & ++ \\
\hline Dentate gyrus & - & ++ & ++ \\
\hline \multicolumn{4}{|l|}{ Cerebellum } \\
\hline Purkinje cells & + & +++ & +++ \\
\hline Molecular layer & +++ & + & + \\
\hline \multicolumn{4}{|l|}{ Hypothalamus } \\
\hline Suprachiasmatic nucleus & +++ & ++ & ++ \\
\hline PVN & +++ & NA & ++ \\
\hline Medial preoptic nucleus & + & + & + \\
\hline Medial preoptic area & + & ++ & + \\
\hline Supraoptic nucleus & +++ & ++ & ++ \\
\hline Ventromedial nucleus & ++ & + & ++ \\
\hline Arc & ++++ & + & ++ \\
\hline \multicolumn{4}{|l|}{ Thalamus } \\
\hline Mediodorsal nucleus & + & + & + \\
\hline Ventrolateral nucleus & + & + & + \\
\hline Reticular nucleus & ++ & + & + \\
\hline \multicolumn{4}{|l|}{ Midbrain } \\
\hline Supramamillary nucleus & ++ & ++ & ++ \\
\hline Medial mammillary nucleus & ++ & + & + \\
\hline \multicolumn{4}{|l|}{ Hindbrain } \\
\hline Locus ceruleus & +++ & NA & ++ \\
\hline Ventral pontine reticular nucleus & + & ++ & + \\
\hline Caudal pontine reticular nucleus & + & + & + \\
\hline Solitary tract nucleus & ++ & + & + \\
\hline Trigeminal nucleus & ++ & NA & + \\
\hline \multicolumn{4}{|l|}{ Ventricular structures } \\
\hline Ependymal layer (tanycytes) & +++ & - & ++ \\
\hline Subfornical organ & +++ & + & ++ \\
\hline Subcommisural organ & +++ & NA & +++ \\
\hline
\end{tabular}

${ }^{a}$ Expression levels are indicated on a semiquantitative scale, where - indicates absence, and the number of crosses $(+)$ indicates relative expression levels. NA, specific dataset does not exist. The data from the Allen Brain Atlas are freely available at http://mouse.brain-map.org/experiment/show/75551474.

(Buell et al., 1996). To validate the reporter mice, we used this region as a positive control. In accord, we found abundant and strong tdTomato expression in the olfactory epithelium of reporter mice, but not in wild-type littermates (Fig. $1 A ; n=4$ mice). For subsequent evaluations, we focused on the brain. tdTomato expression in peripheral organs, such as the lungs (Miklavc et al., 2013) and heart (Yang et al., 2014) was not studied, but the mice are available via The Jackson Laboratory (JAX\#029332) for others to do so.

\section{Brain-wide evaluation of tdTomato expression in P2rx4 tdTomato reporter mice}

Benefitting from previous detailed analyses of P2X4 mRNA (Buell et al., 1996; Collo et al., 1996; Lein et al., 2007), we evaluated tdTomato expression in coronal brain sections ( $n=4$ mice). We detected tdTomato-expressing cells throughout the brain, with the cytosolic protein being readily observed in neuronal somata and dendrites. Representative images are shown in Figure 1 , and expression patterns are compared with mRNA distribu- 


\section{A Hippocampal saline microinjections}
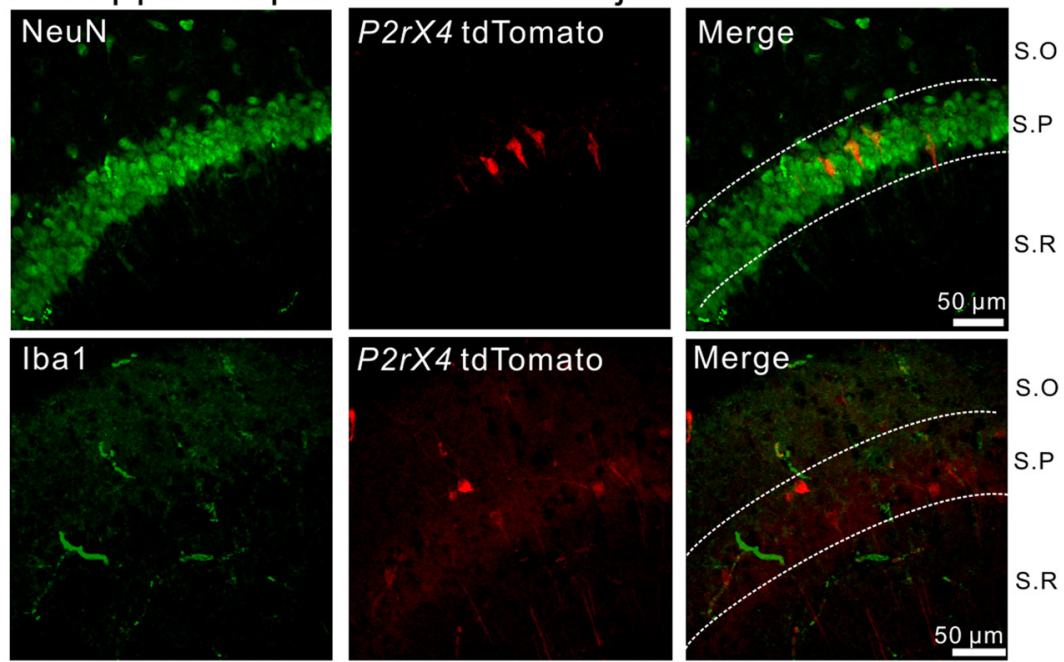

B Hippocampal LPS microinjections
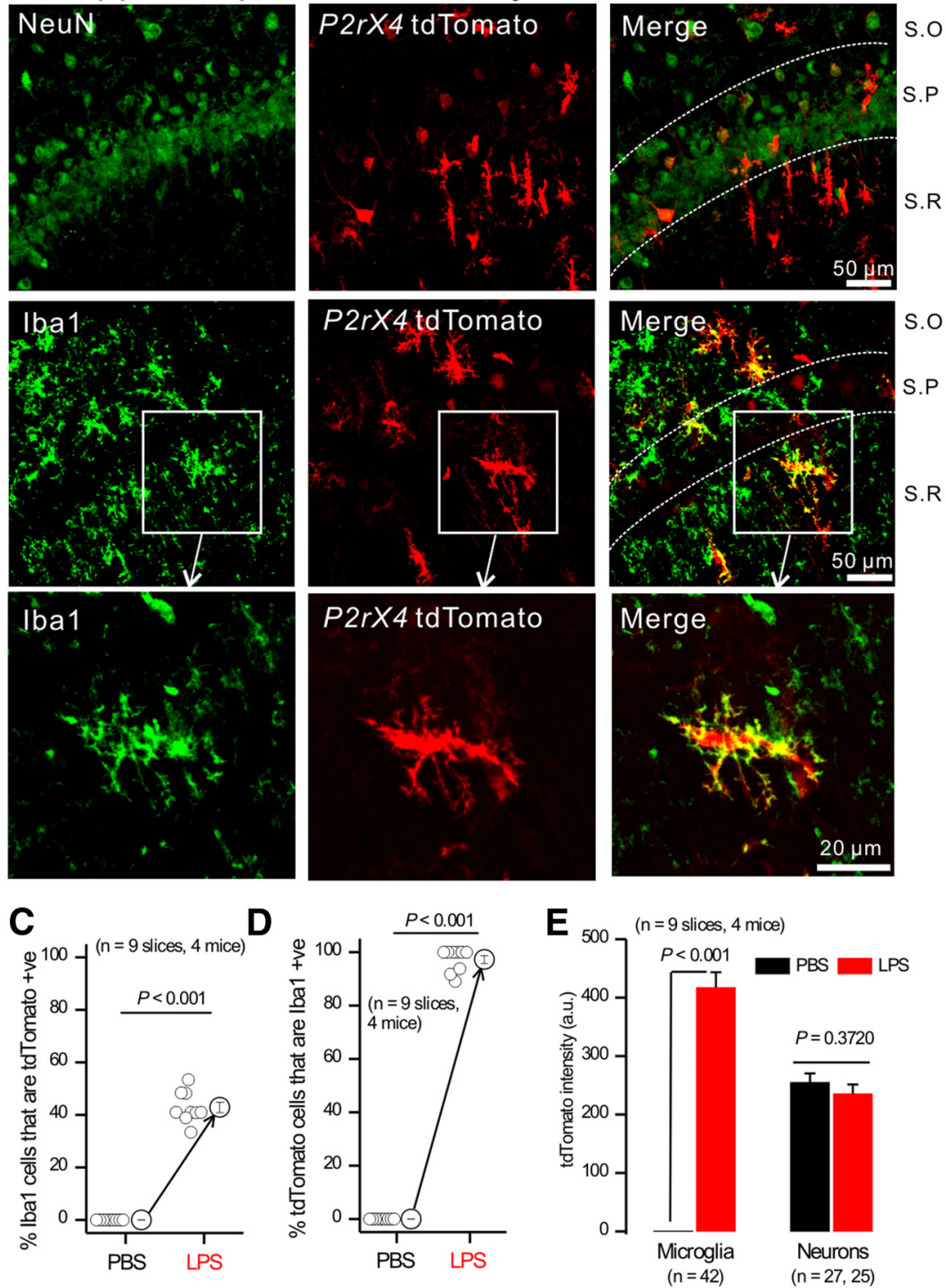

Figure 2. $\quad$ tdTomato expression was upregulated in microglia from P2rx4 tdTomato mice by LPS. $\boldsymbol{A}, \boldsymbol{B}$, Representative IHC images of NeuN and tdTomato (top) as well as Iba1 and tdTomato (bottom) from CA1 regions from $P 2$ rx4 tdTomato mice injected with PBS $(\boldsymbol{A})$ or $4 \mu \mathrm{g}$ LPS $(\boldsymbol{B})$. S.0, Stratum oriens; S.P, stratum pyramidale; S.R, stratum radiatum. C, Percentage of Iba1-positive cells that were tdTomato-positive as measured from panels, such as in $\boldsymbol{A}, \boldsymbol{B}$. D. Percentage of tdTomato-positive cells that were tion in Table 1. Briefly, we detected strong tdTomato expression in the glomerular layer in the main and accessory olfactory bulbs (Fig. 1Bi). These regions likely represent axonal projections from olfactory epithelial layers (Fig. 1A). Moderate labeling was also observed in mitral cells with clearly visible dendrites (Fig. $1 B i$, red arrow). Little labeling was observed in the striatum (Fig. 1Bii). In the case of the cerebral cortex, generally low and sparse labeling was observed in the entorhinal cortex and piriform cortex; labeled cortical neurons mainly clustered in layers II and III (Fig. 1Biv, panels 6 and 7). In the hippocampus, pyramidal neurons were sparsely labeled in the CA1 region (Fig. 1Biv, panel 4). Consistent with past electrophysiology (Haustein et al., 2014), no labeling was observed in CA3 or dentate gyrus neurons (Fig. 1Biv, panel 5). In the cerebellar cortex, some Purkinje cells exhibited marked levels of labeling, but most cells did not (Fig. 1Bvi, panel 2). However, strong labeling was observed in stellate cells in the molecular layer of the cerebellum (Fig. 1Bvi, panel 1).

A series of distinct nuclei heavily expressed tdTomato in the hypothalamus (Stojilkovic, 2009). These included the paraventricular nucleus, supraoptic nucleus, suprachiasmatic nucleus, and the Arc. In the paraventricular and suprachiasmatic nuclei, tdTomato-expressing cells were evenly distributed in both brain areas, with clearly visible tdTomato expressing dendrites (Fig. 1Biii,Biv, red arrows). In the Arc, two clearly discernible cell types were observed: one population displayed neuronal morphology and the other more stellate population lined the third ventricle and displayed long thin processes ( $>100 \mu \mathrm{m}$ long) that were indicative of tanycytes (Fig. 1Biv, panel 2). Less dense tdTomato-expressing cells were seen in the dorsal medial hypothalamus (Fig. 1Biv, panel 3). We also observed that ependymal cells in various parts of the brain showed strong tdTomato expression. For example, high tdTomato expression was observed in the subcommissural organ, a small ependymal gland of the circumventricular system that is located in the dorsocaudal region of the third ventricle (Fig. $1 B v)$. Expression in tanycytes and the subcommissural organ is consistent with proposed roles for ATP signaling (Frayling et

Iba1-positive as measured from panels, such as in $\boldsymbol{A}, \boldsymbol{B} . \boldsymbol{E}$, tdTomato fluorescence intensity within microglia and neurons from experiments, such as in $\boldsymbol{A}, \boldsymbol{B}$. 
al., 2011). In the spinal cord, low levels of tdTomato were observed in motor neurons (Fig. 1C), which is consistent with past studies in healthy, noninjured mice (Bo et al., 1995).

As a summary, Figure 1 reports representative images of several brain areas where tdTomato expression was observed. We used such images from the entire brain to assemble Table 1, which compares in a qualitative manner tdTomato expression with past reports of P2X4 mRNA expression for several regions (Buell et al., 1996; Collo et al., 1996; Lein et al., 2007). Across multiple brain regions, strong concordance was observed between tdTomato and P2X4 mRNA (Table 1), indicating that the P2rx4 tdTomato reporter mice faithfully represent P2X4 expression. However, tdTomato does not report $\mathrm{P} 2 \mathrm{X} 4$ receptors because it is a cytosolic reporter and is not tagged to the $\mathrm{P} 2 \mathrm{X} 4$ receptor subunit protein.

tdTomato upregulation in hippocampal microglia after in vivo LPS injections

$\mathrm{P} 2 \mathrm{X} 4$ receptors are significantly upregulated in microglia when they become activated in vivo (Tsuda et al., 2003; Ulmann et al., 2008, 2010, 2013). Mechanistic studies in vitro show that upregulation occurs both via altered trafficking and via increased P2X4 gene expression (Raouf et al., 2007; Toulme et al., 2010; Toulme and Khakh, 2012; Xu et al., 2014). Expression of tdTomato in P2rx4 tdTomato reporter mice is under the control of the normal $\mathrm{P} 2 \mathrm{X} 4$ regulatory elements in the genomic DNA contained within the BAC (Yang and Gong, 2005). We examined tdTomato expression in hippocampal microglia in control P2rx4 tdTomato mice and in those that had received hippocampal LPS microinjections in vivo (Hamby et al., $2012)$ to induce microglial activation $(n=$ 4 control mice and $n=4$ LPS-treated mice). In control mice, tdTomato expression in the hippocampus was restricted to a sparse neuronal population in the pyramidal cell layer, and no colocalization was observed with the microglia marker Ibal (Fig. $2 A ; n=4$ ). In contrast, in LPSinjected mice, we observed dramatically increased tdTomato expression in cells with microglia-like morphology across all regions of the hippocampus (Fig. $2 B, E$; $n=4)$. This abundant tdTomato expression did not colocalize with neuronal nuclei $(\mathrm{NeuN})$ a vertebrate nervous system and neuron-specific nuclear protein, but did colocalize with Iba1 (Fig. $2 B ; n=4$ ). Hence, there was a significant and substantial increase in the percentage of Iba1-positive cells that expressed tdTomato following
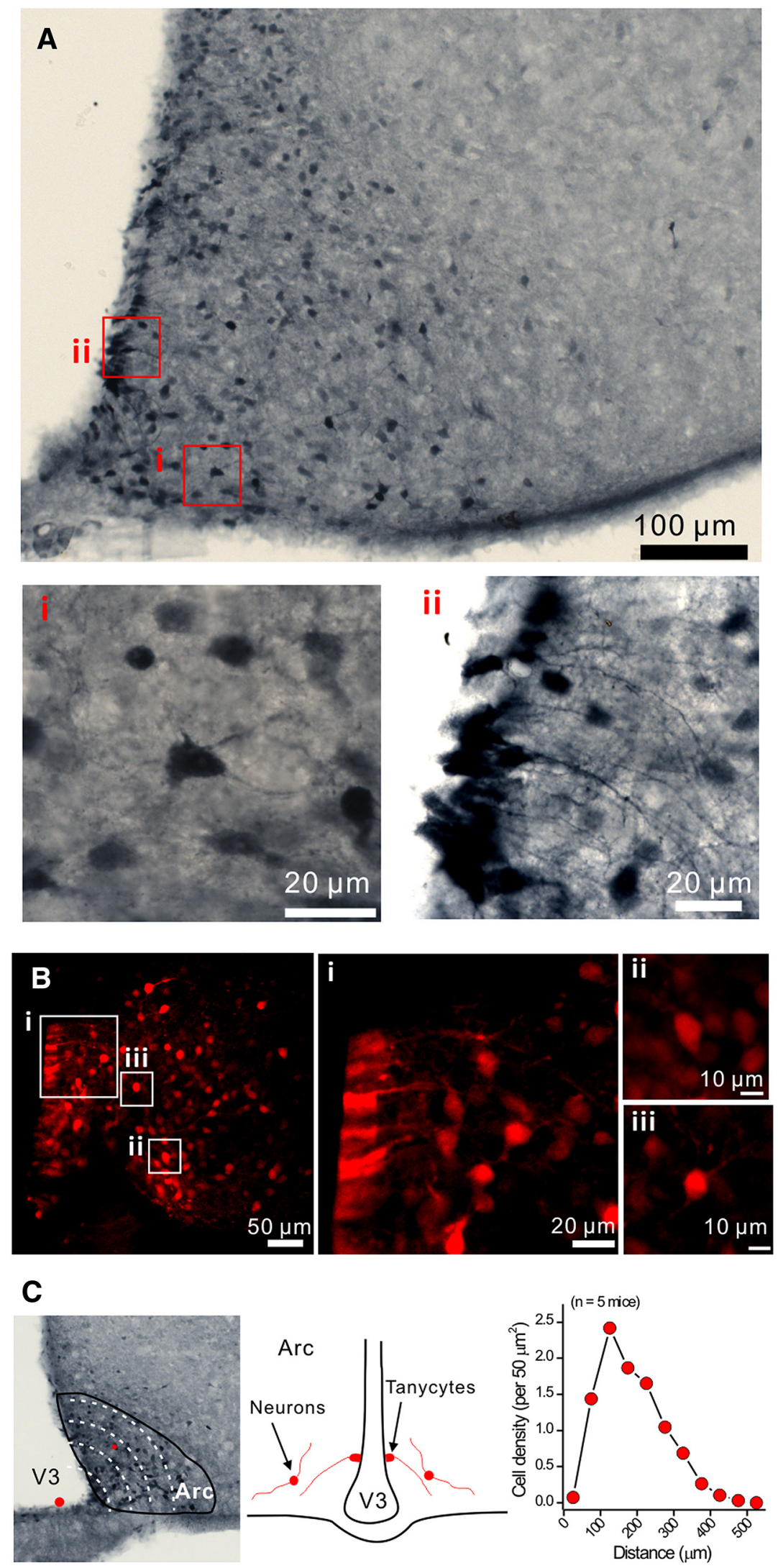

Figure 3. tdTomato-positive cells in the arcuate nucleus. $\boldsymbol{A}$, Representative IHC images of tdTomato-positive cells in the arcuate nucleus. Ai, Representative image of neurons. Aii, Representative image of tanycytes. B, Confocal images of tdTomato-positive cells from live brain slices. Bi, Tanycytes. Bii, Biii, Neurons. C, Distance of Arc tdTomato-positive neurons from the bottom of the third ventricle (medium eminence). Diagram represents the positions of tanycytes and neurons. Right panels, The cell density of tdTomato-positive neurons per $50 \mu \mathrm{m}^{2}$ was plotted against the distance to the medium eminence. 


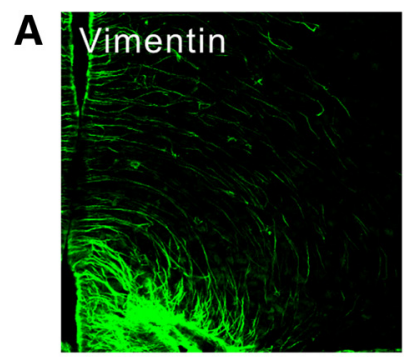

B

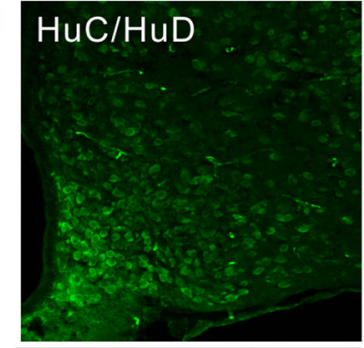

C

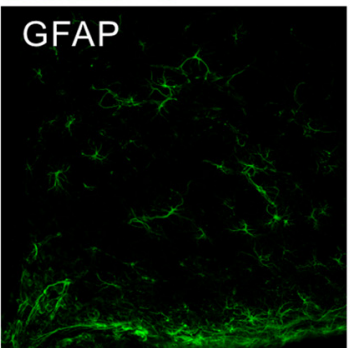

D

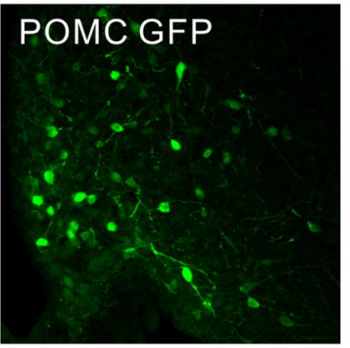

E

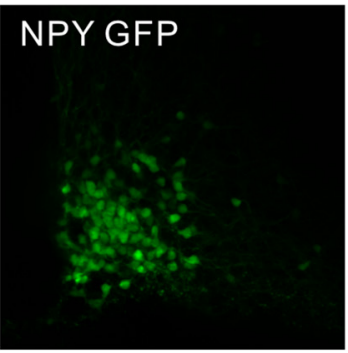

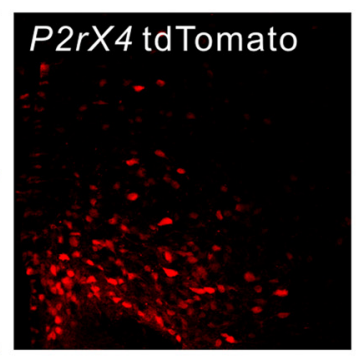
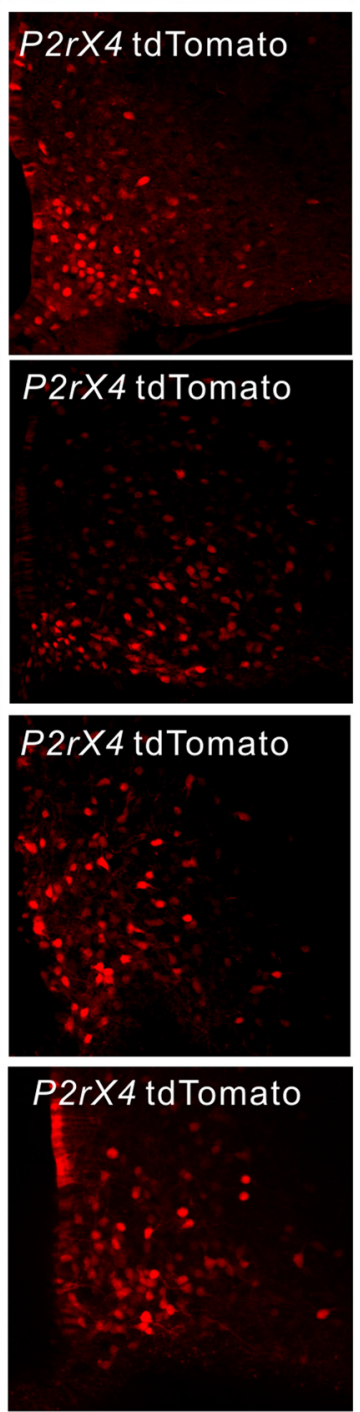
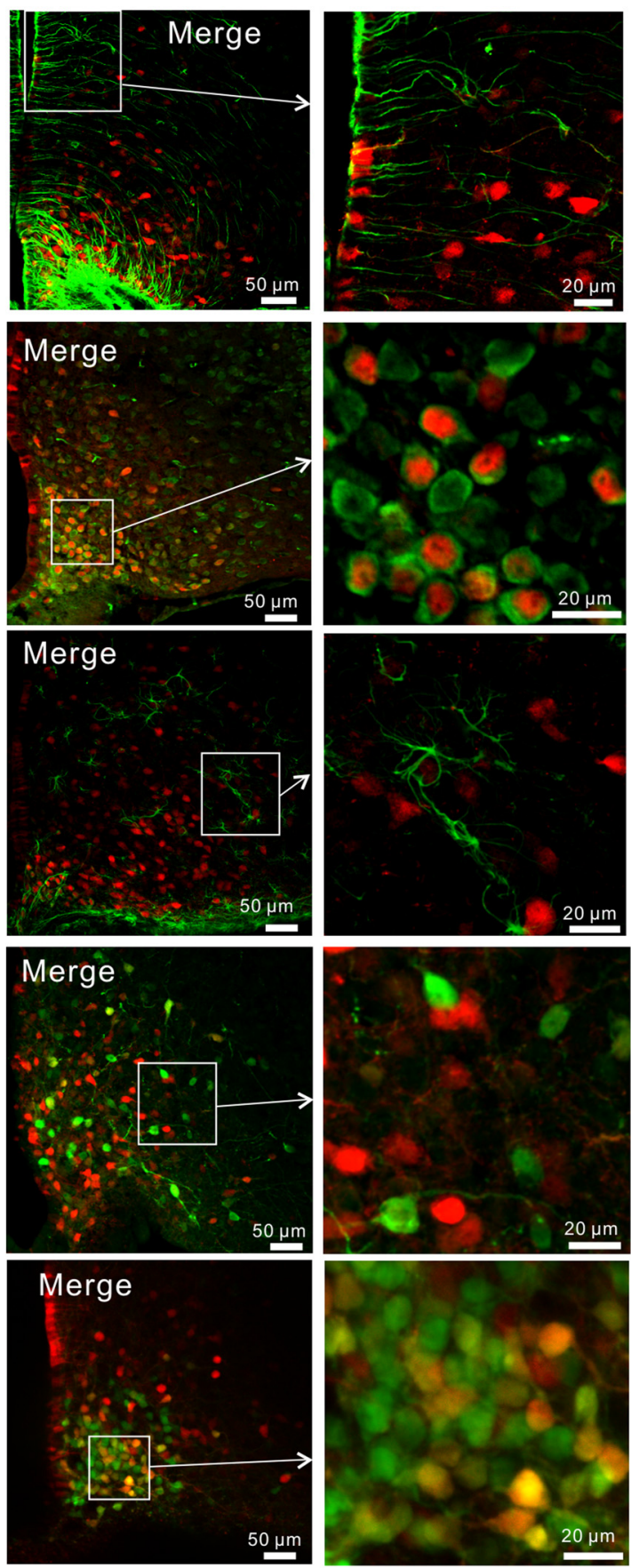

Figure 4. Cellular identity of tdTomato-positive cells in the arcuate nucleus. $\boldsymbol{A}-\boldsymbol{E}$, Representative images for colocalization of tdTomato-positive cells with markers for tanycytes (vimentin), neurons (HuC/HuD), astrocytes (GFAP), as well as GFP from P0MC GFP and NPY GFP reporter mice. Average data for the percentage of P2X4-tdTomato cells that colocalized with these cell-specific markers are reported in the text.

LPS (Fig. $2 C ; n=4$ ), and essentially all hippocampal tdTomatopositive cells observed from LPS-injected mice were microglia (Fig. $2 D ; n=4$ ). Moreover, the tdTomato fluorescence intensity increased significantly in microglia following LPS but was not altered in neurons (Fig. $2 E ; n=4$ ). These data show that tdTomato expression from BAC P2rx4 tdTomato reporter mice was increased, as expected, in activated microglia.

\section{Cellular identity of tdTomato-expressing cells in Arc}

tdTomato expression was particularly high in the Arc (Fig. 1; Table 1), a hypothalamic nucleus that controls feeding and energy homeostasis (Sternson and Atasoy, 2014). Consistent with tdTomato expression (Fig. 1Biv), RNAseq analyses show that Arc neurons abundantly express P2X4 mRNA (Henry et al., 2015); this prompted us to explore $\mathrm{P} 2 \mathrm{X}$ responses in more detail.

Figure 3 shows examples of tdTomato-expressing cells, which were distributed across the Arc and displayed typical neuronal morphologies with dendrites (Fig. 3Ai). Tanycytes (Langlet, 2014) were the other abundant cell type expressing tdTomato (Fig. 3Aii). tdTomato expression was also readily observed in Arc in both neurons and tanycytes by confocal microscopy in live brain slices (Fig. 3B), demonstrating that the native fluorescence of tdTomato could be visualized without the use of antibody 
labeling. tdTomato-positive neurons were most abundant $<100 \mu \mathrm{m}$ away from the medial eminence $(n=5$ mice; Fig. $3 C)$. The medial eminence is fenestrated with blood vessels and is considered to reside outside the blood-brain barrier. The close proximity of tdTomato-positive neurons to the medial eminence suggests that these cells may sense circulating hormones.

We sought to determine the identity of the Arc cells expressing tdTomato by IHC and by crossing the P2rx4 tdTomato mice with reporter mice expressing GFP in either AgRP-NPY or POMC neurons, which are the predominant populations in this brain area (Atasoy et al., 2012; Langlet, 2014). The vast majority (94 $\pm 3 \%$ ) of the tdTomato-positive cells located on the border with the third ventricle displayed vimentin-positive processes, which identifies them as tanycytes (Fig. $4 A ; n=4)$. All of the other tdTomatopositive cells colocalized with the neuronal marker $\mathrm{HuC} / \mathrm{HuD}$ (100\%), but not with GFAP $(0 \%)$, indicating that they are neurons and not GFAP-positive astrocytes (Fig. $4 B, C ; n=4$ mice). However, only $\sim 50 \%$ of the $\mathrm{HuC} / \mathrm{HuD}$-positive neurons were tdTomato-positive (Fig. 4B; $n=4$ mice), implying that the tdTomatopositive neurons represent a specific Arc population. By crossing the P2rx4 tdTomato mice with POMC GFP mice, we found that $10 \pm 2 \%$ of the labeled neurons colocalized (Fig. $4 D ; n=5$ mice). In contrast, by crossing P2rx4 tdTomato mice with AgRP-NPY GFP reporter mice, we found $56 \pm 2 \%$ colocalization between labeled neurons (Fig. $4 E ; n=4$ mice). Together, these studies provide strong evidence that the major Arc cell type that expresses tdTomato is the AgRP-NPY neuronal population. The unaccounted for $\sim 30 \%$ of tdTomato-positive neurons that did not colocalize with GFP in AgRPNPY or POMC reporter mice may represent a third population of Arc neurons or incomplete penetrance/labeling of AgRPNPY neurons in the transgenic GFP reporter line. We favor the latter possibility, given recent cell specific RNAseq data, which showed abundant P2X4 mRNA in AgRP-NPY neurons (Henry et al., 2015).

In some cases (e.g., Fig. 4B), the tdTomato appeared nuclear. This is consistent with past reports with this fluorescent protein and does not detract from its use as a cell reporter (Gee et al., 2014; Besser et al., 2015).

\section{Electrophysiological recording from tdTomato-} expressing neurons

We used fluorescence-guided electrophysiology to record the basic properties of tdTomato-expressing Arc neurons in relation to $30 \mu \mathrm{M}$ APV.
A Wild-type mice
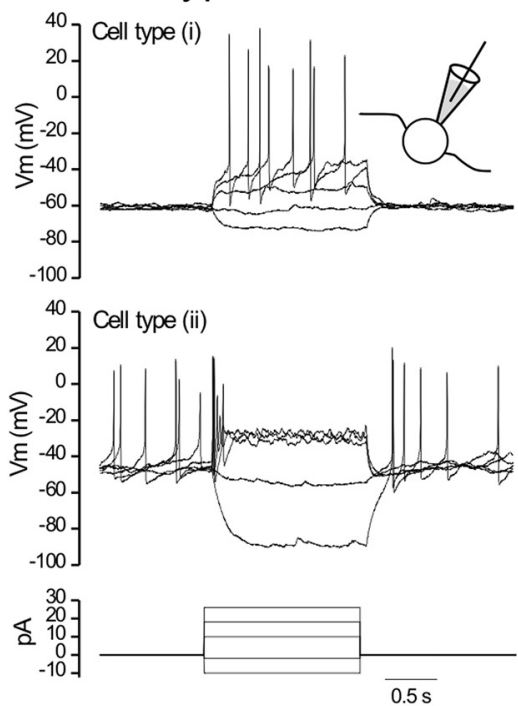

B P2rX4 tdTomato mice
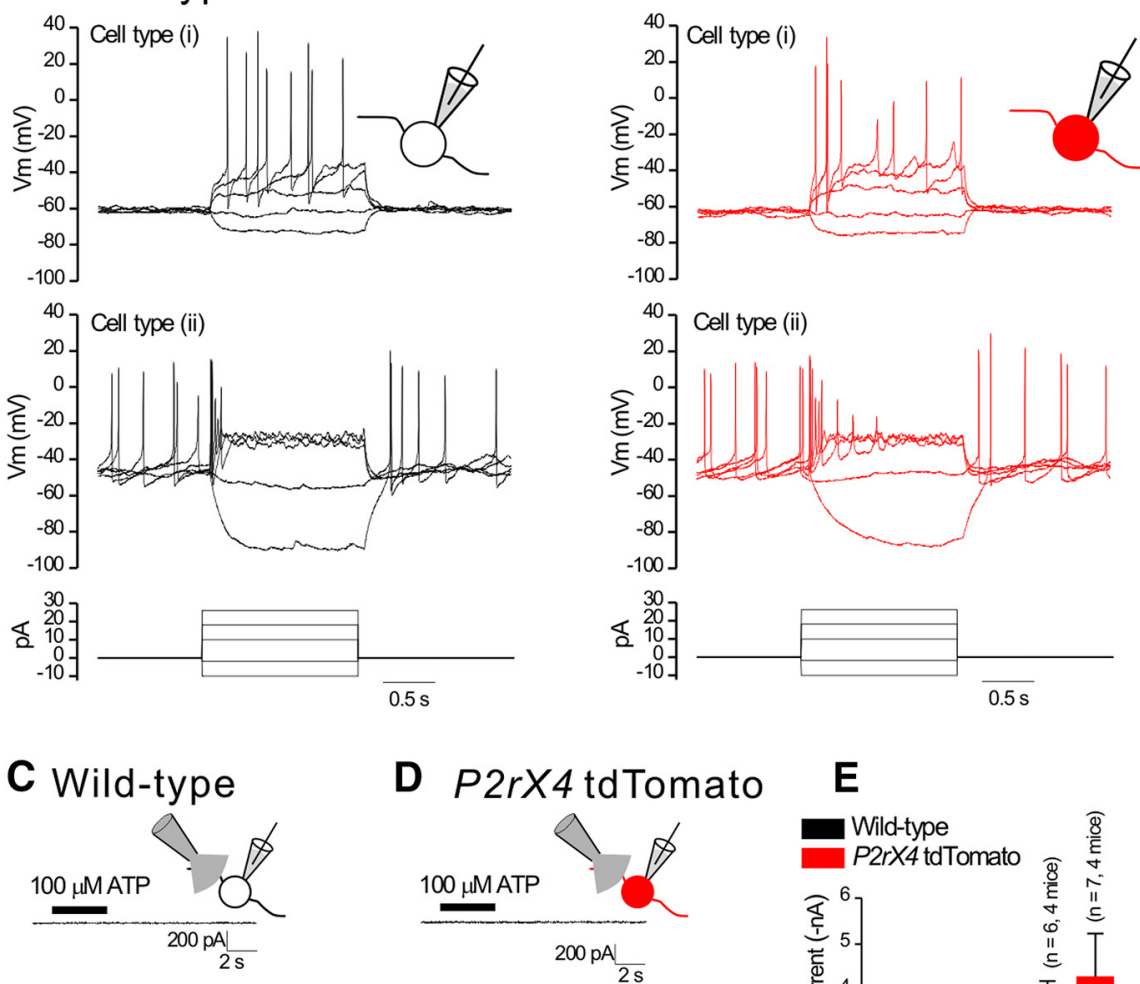

D P2rX4 tdTomato
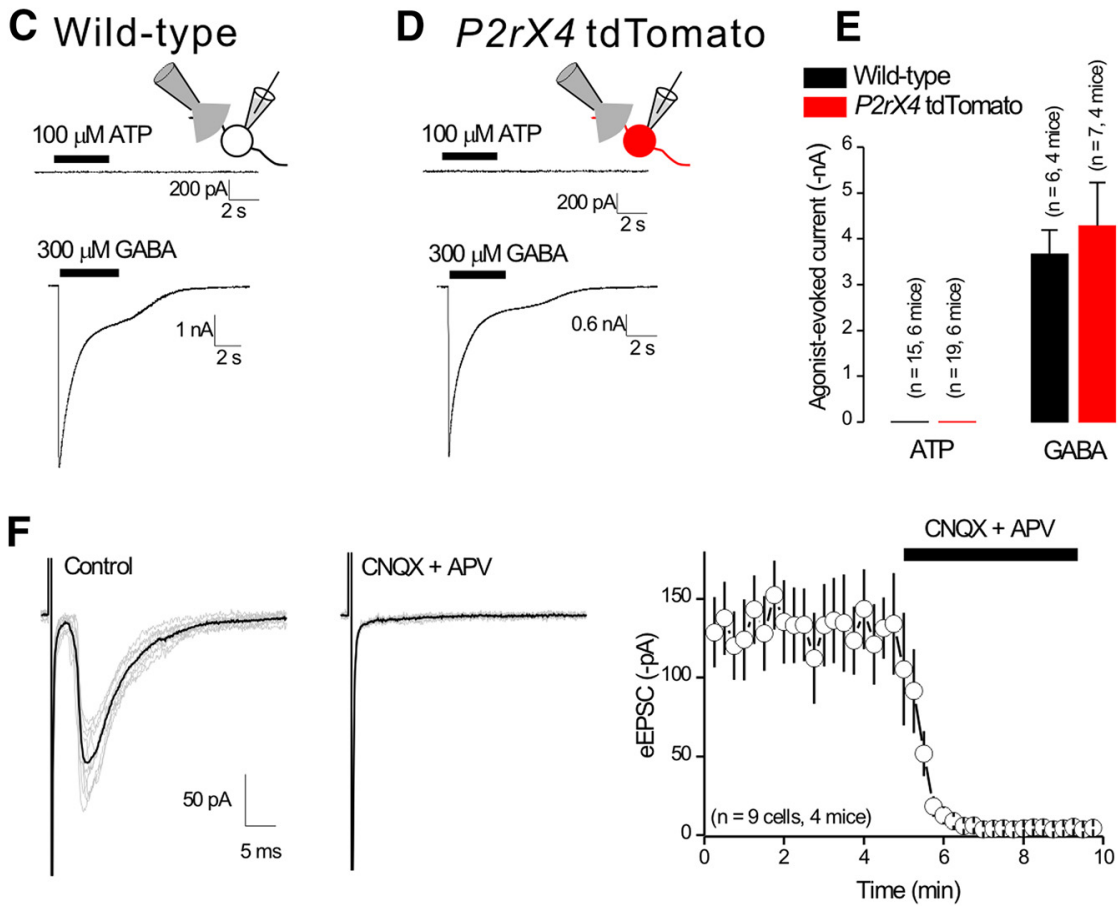

Figure 5. Electrophysiological properties of neurons from the arcuate nucleus in wild-type and P2rx4 tdTomato mice. $\boldsymbol{A}, \boldsymbol{B}$, Representative waveforms of membrane potentials recorded in current clamp from arcuate nucleus neurons in wild-type mice $(\boldsymbol{A})$ and tdTomato-positive neurons from P2rx4 tdTomato mice $(\boldsymbol{B})$. Bottom panels, Current injection protocol. $\boldsymbol{C}, \boldsymbol{D}$, Representative traces for ATP-evoked and GABA-evoked currents recorded from arcuate nucleus neurons from wild-type mice $(\boldsymbol{C})$ and tdTomatopositive neurons in P2rx4 tdTomato mice (D) in response to 5 s puff applications of $100 \mu \mathrm{m}$ ATP or $300 \mu \mathrm{m}$ GABA. No ATP-evoked currents were detected. $\boldsymbol{E}$, Average data for experiments, such as those in $\boldsymbol{C}, \boldsymbol{D}$. F, Representative traces of eEPSCs recorded from $\mathrm{tdTomato-positive} \mathrm{neurons} \mathrm{in} \mathrm{the} \mathrm{presence} \mathrm{of} 10 \mu \mathrm{m}$ bicuculline. Right, The eEPSCs were completely blocked by $10 \mu \mathrm{M}$ CNQX and

those recorded from wild-type mice (Fig. $5 ; n=4$ ). Two distinct types of neurons were observed in both genotypes. Approximately half the neurons displayed resting membrane potentials at $\sim-47 \mathrm{mV}$, input resistances at $\sim 3 \mathrm{G} \Omega$, and spontaneous action potential firing at $\sim 1 \mathrm{~Hz}$. The other half of the cells displayed more hyperpolarized resting membrane potentials at $\sim-63 \mathrm{mV}$, lower input resistances at $\sim 2 \mathrm{G} \Omega$, and no spontaneous action potential firing (Fig. $5 A, B$; average data in Table 2). However, there were no significant differences across these metrics between 


\begin{tabular}{|c|c|c|c|c|}
\hline & Tyре & $\begin{array}{l}\text { Wild-type ( } n=4 \text { mice) } \\
\text { (no. of neurons) }\end{array}$ & $\begin{array}{l}\text { P2rx4 tdTomato ( } n=4 \text { mice) } \\
\text { (no. of neurons) }\end{array}$ & $p$ \\
\hline $\begin{array}{l}\text { Resting membrane } \\
\text { potential (mV) }\end{array}$ & $\begin{array}{l}i \\
i i\end{array}$ & $\begin{array}{l}-47.8 \pm 1.0(7) \\
-63.0 \pm 0.5(8)\end{array}$ & $\begin{array}{l}-47.8 \pm 0.7(7) \\
-63.9 \pm 0.4(7)\end{array}$ & $\begin{array}{l}0.99 \\
0.20\end{array}$ \\
\hline $\begin{array}{l}\text { Resting firing } \\
\text { frequency }(\mathrm{Hz})\end{array}$ & $\begin{array}{l}i \\
i i\end{array}$ & $\begin{array}{l}1.0 \pm 0.3(7) \\
0(8)\end{array}$ & $\begin{array}{l}0.7 \pm 0.2(7) \\
0(7)\end{array}$ & $\begin{array}{l}0.44 \\
-\end{array}$ \\
\hline $\begin{array}{l}\text { Input resistance } \\
(\mathrm{G} \Omega)\end{array}$ & $\begin{array}{l}i \\
i i\end{array}$ & $\begin{array}{l}3.5 \pm 0.5(7) \\
2.0 \pm 0.2(8)\end{array}$ & $\begin{array}{l}2.4 \pm 0.3(7) \\
1.6 \pm 0.2(7)\end{array}$ & $\begin{array}{l}0.08 \\
0.21\end{array}$ \\
\hline Rheobase (pA) & $\begin{array}{l}i \\
i i\end{array}$ & $\begin{array}{l}\mathrm{NA}(7) \\
\quad 11.0 \pm 2.4(8)\end{array}$ & $\begin{array}{l}\mathrm{NA}(7) \\
\quad 15.1 \pm 1.4(7)\end{array}$ & $\begin{array}{l}\text { NA } \\
0.17\end{array}$ \\
\hline
\end{tabular}

${ }^{a}$ NA, Not applicable (as these neurons fired at rest, which means a rheobase was not measured) ; - test could not be performed because the neurons of this class did not fire. Rheobase indicates the minimum amount of current needed to cause the neurons to fire action potentials. The two broadly observed types of neurons ( $i$ and $i$ ) were indiscernible in wild-type and $P 2 r x 4$ tdTomato mice. $p$ values are from statistical comparisons between wild-type and P2rx4 tdTomato mice for the metrics listed in the table.

neurons recorded from wild-type and P2rx4 tdTomato mice $(p>0.05$; Table 2$)$. This provides evidence that expression of tdTomato does not detectably alter the basic properties of Arc neurons (Fig. $5 A, B$; Table 2).

To explore the function of $\mathrm{P} 2 \mathrm{X} 4$ receptors in Arc neurons, we puffed $100 \mu \mathrm{M}$ ATP onto their somata at $-60 \mathrm{mV}$ but failed to measure ATP-evoked inward currents that would be indicative of somatic functional P2X4 expression in either wild-type or P2rx4 tdTomato mice (Fig. $5 C-E ; n=6$ mice for both genotypes). However, we measured robust $300 \mu \mathrm{M}$ GABA-evoked currents in both genotypes (Fig. $5 C-E ; n=4$ mice for both genotypes). We also examined eEPSCs onto Arc neurons and found that eEPSCs were completely blocked with a combination of $10 \mu \mathrm{M}$ CNQX and $30 \mu \mathrm{M}$ APV to block AMPA and NMDA receptors, respectively (Fig. 5F; $n=4$ mice). Together, these data suggest that there were few, if any, functional P2X4 receptors on the somata of Arc neurons; there was also no evidence for fast ATP synaptic transmission in this nucleus.

\section{Evidence that presynaptic $\mathrm{P} 2 \mathrm{X} 4$ receptors regulate $\mathrm{GABA}$ release onto POMC neurons}

In some brain areas, $\mathrm{P} 2 \mathrm{X}$ receptors are found in presynaptic nerve terminals where their activation regulates neurotransmitter release probability. This was first shown for sensory neurons (Gu and MacDermott, 1997; Khakh and Henderson, 1998; Lê et al., 1998) and is exemplified by presynaptic P2X4-like responses in the nucleus tractus solitarius (Shigetomi and Kato, 2004). Because AgRP-NPY neurons send GABAergic projections to Arc POMC neurons (Cowley et al., 2001), we crossed P2rx4 tdTomato mice with POMC GFP mice and, using confocal imaging in live slices, we observed little overlap between the fluorescent proteins (Fig. 6A,B). This is in accord with the IHC data in Figure 4. However, the POMC GFP transgenic mice allowed us to record from identified GFP-expressing POMC neurons and then puff ATP nearby to determine whether it affected GABA release from AgRP-NPY neurons onto POMC neurons (Fig. $6 C)$. In the presence of $250 \mathrm{nM}$ TTX and $10 \mu \mathrm{M} \mathrm{Cd}^{2+}$ to block action potentials and voltage-gated $\mathrm{Ca}^{2+}$ channels, respectively, we found that ATP applications largely and reproducibly increased mIPSC frequency without changing their amplitude (Fig. $6 D, E ; n=4$ mice). Thus, in 9 of 11 neurons, the mIPSC frequency was $1.3 \pm 0.5$ $\mathrm{Hz}$ before ATP and $10.3 \pm 0.3 \mathrm{~Hz}$ during ATP applications; the amplitudes were identical at $49.5 \pm 6.6$ and $50.2 \pm 3.6 \mathrm{pA}$, respectively (Fig. 6E). Puffs of ACSF were ineffective and all mIPSCs were abolished in the presence of bicuculline (Fig. $6 D, E ; n=4$ mice). As expected for presynaptic facilitation, quantal analyses $(n=9$ cells and 4 mice) revealed that ATP shifted the mIPSC interevent interval distributions to shorter times but did not change the amplitude dis- tributions (Fig. $6 F$ ). Representative traces are shown in Figures $6 D$ and $7 A$. The ATP effect was extremely robust.

In accord with a role for P2X4 receptors, the stable ATP congener ATP $\gamma \mathrm{S}$ was also effective at elevating mIPSC frequency without changing amplitude. Thus, the mIPSC frequency and amplitudes were $3.4 \pm 1.3 \mathrm{~Hz}$ and $70.7 \pm 8.8 \mathrm{pA}$ before ATP $\gamma \mathrm{S}$ puffs, and during ATP $\gamma S$ puffs they were $6.2 \pm 1.8 \mathrm{~Hz}$ and $74.7 \pm$ $7.7 \mathrm{pA}$, respectively $(p=0.017$ for frequency and $p=0.4202$ for amplitude; $n=14$ cells, $n=4$ mice). However, Bz-ATP and $\alpha, \beta$-meATP, which are not effective $\mathrm{P} 2 \mathrm{X} 4$ receptor agonists, did not significantly change mIPSC frequency or amplitude (Table 3). Consistent with a role for P2X4 receptors, the ATP effect on mIPSC frequency was blocked by $10 \mu \mathrm{M}$ PPADS, which efficiently antagonizes mouse P2X4 receptors (Jones et al., 2000). The ATP effect was also abolished in $\mathrm{Ca}^{2+}$ free extracellular solutions, which is expected because $\mathrm{P} 2 \mathrm{X} 4$ receptors are $\mathrm{Ca}^{2+}$ permeable (Egan and Khakh, 2004) and P2X receptor-mediated presynaptic facilitation relies on $\mathrm{Ca}^{2+}$ entry (Khakh, 2001; Khakh and North, 2012). The ATP effect on mIPSC frequency was not, however, blocked by applications of $30 \mu \mathrm{M}$ MRS2179 (Fig. 7B), which antagonizes $\mathrm{P} 2 \mathrm{Y}$ receptors (Bowser and Khakh, 2004). Moreover, although not strictly diagnostic of P2X4 receptors alone, slow desensitization kinetics can be used to identify P2X4 receptors in responses evoked by ATP (North, 2002). In accord with a role for $\mathrm{P} 2 \mathrm{X} 4$ receptors, the ATP-evoked increase in mIPSC frequency desensitized with a time constant of $\sim 71 \mathrm{~s}$ during 2 min applications of $100 \mu \mathrm{M} \mathrm{ATP} \mathrm{(Fig.} 7 C$; $n=10$ cells from 5 mice). Recombinant P2X4 receptors also display minimal tachyphylaxis during repeated applications of ATP (North, 2002). In accord, repeated ATP applications reliably increased mIPSC frequency with little tachyphylaxis (Figs. $6 D, 7 D ; n=28$ cells from 9 mice), although it remains possible that the P2X4 receptors may have partially desensitized but were still capable of providing sufficient calcium flux to evoke GABA release. Together, these functional data provide strong evidence that local ATP puffs within the Arc increased GABA release probability from AgRP-NPY neuron terminals onto POMC neurons via $\mathrm{P} 2 \mathrm{X} 4$, which is consistent with tdTomato expression (Figs. 1, 3; Table 1) and with published RNAseq data for Arc AgRP-NPY neurons (Henry et al., 2015).

To bolster our findings in Figure 7, we also performed a specific set of experiments to determine whether local ATP puffs modulated GABAergic IPSCs onto another postsynaptic target of Arc AgRP-NPY neurons. To this end, we repeated experiments, such as those shown in Figures 6 and 7 during whole-cell recordings from paraventricular nucleus (PVN) neurons (Fig. 8A), which receive part of their GABAergic input from AgRP-NPY neurons (Atasoy et al., 2012; Garfield et al., 2015). We observed that $100 \mu \mathrm{M}$ ATP puffs increased mIPSC frequency onto 10 of 31 PVN neurons (Fig. $8 B, D$ ). In the other 21 of 31 neurons, ATP was ineffective (Fig. $8 C, D$ ). Moreover, in the PVN neurons where ATP elevated mIPSC frequency, the effect was abolished by $10 \mu \mathrm{M}$ PPADS or by $\mathrm{Ca}^{2+}$ free extracellular buffers (Fig. $8 F$ ). However, there was a notable and significant difference between recordings from Arc POMC and PVN neurons. For POMC neurons, ATP only elevated mIPSC frequency and did not affect mIPSC amplitude (Fig. 6F). By contrast, in the PVN, ATP applications significantly increased both mIPSC frequency and amplitude (Fig. 7D,E), which is similar to previous work on P2X4-like receptors in the NTS (Shigetomi and Kato, 2004). These data suggest that presynaptic modulation mediated by $\mathrm{P} 2 \mathrm{X} 4$ receptors in terminals of Arc AgRPNPY neurons may vary depending on the postsynaptic target, as has been suggested previously for presynaptic P2X2 (Khakh et al., 2003) 
A

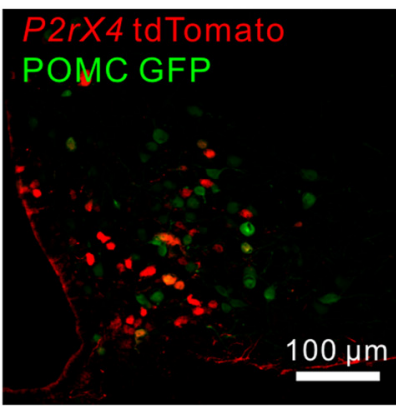

B

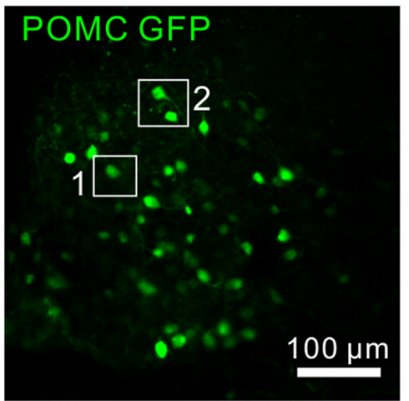

C

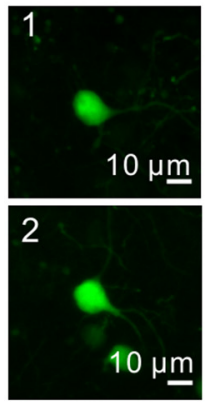

P2rX4 tdTomato neuron

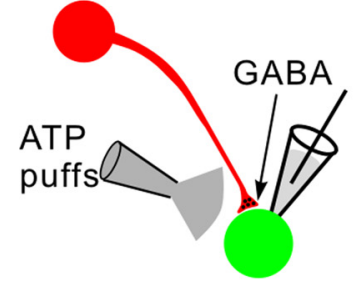

POMC GFP neuron

D $\quad 100 \mu \mathrm{MATP}$ puffs
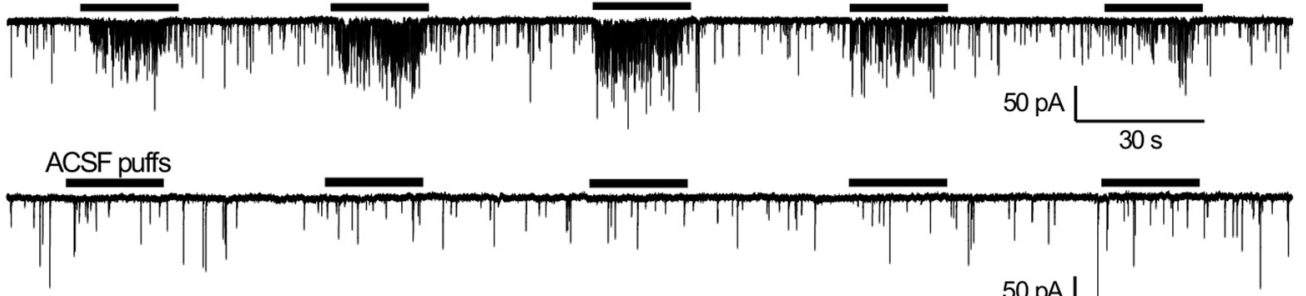

$50 \mathrm{pA}$

$100 \mu$ MATP puffs (in $10 \mu$ M bicucculline)

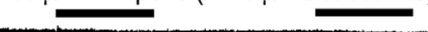

E
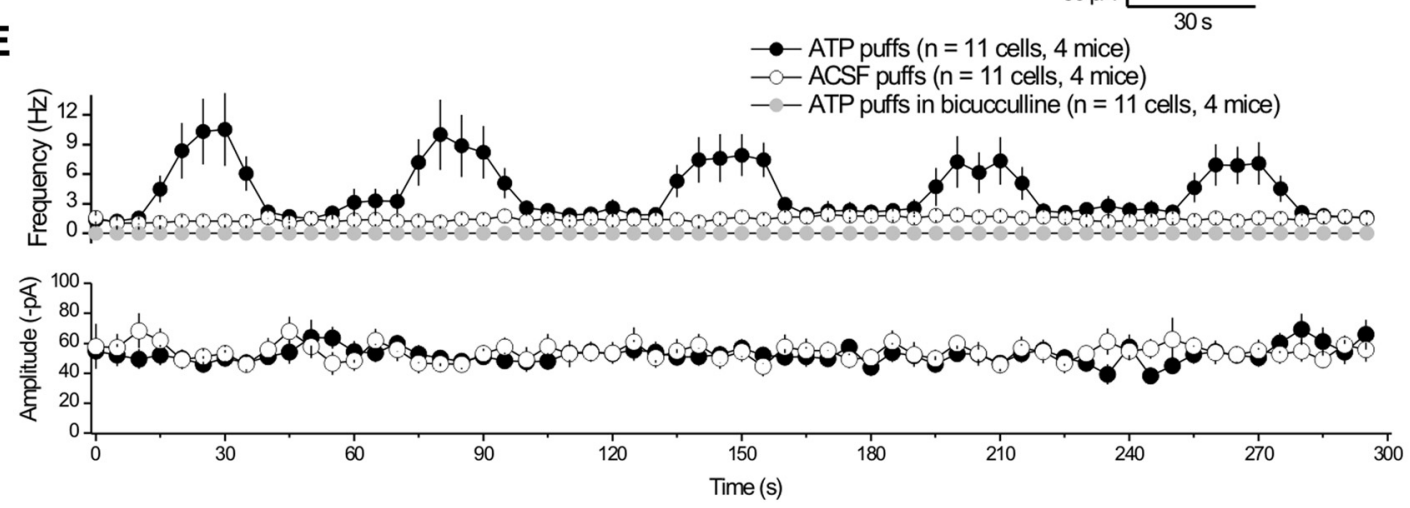

$\mathbf{F}$
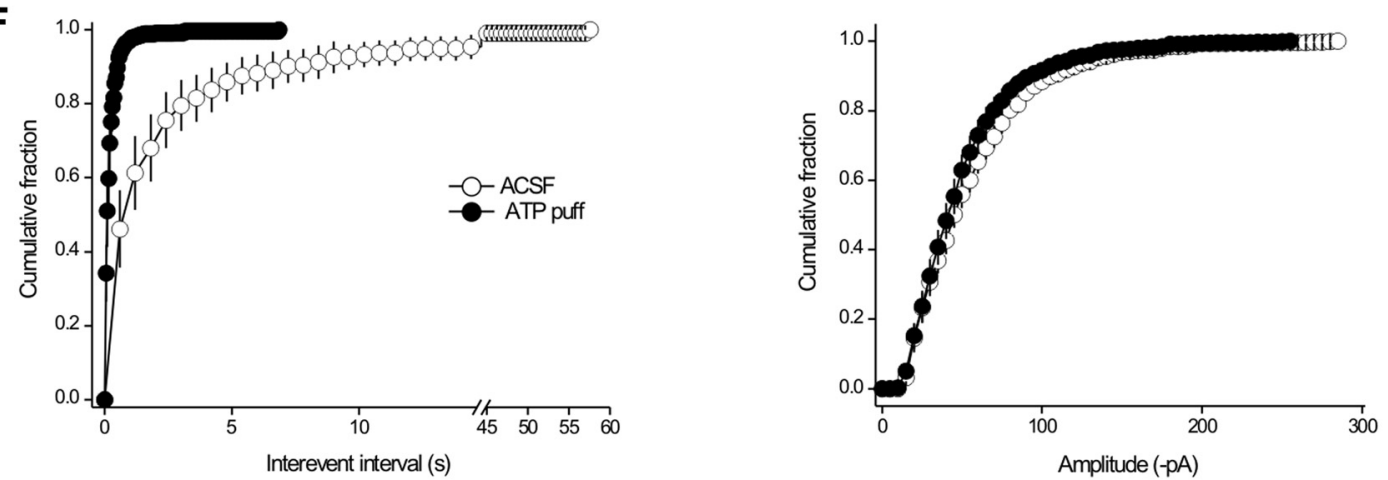

Figure 6. Presynaptic facilitation of mIPSCs onto Arc POMC neurons by ATP. A, There was no colocalization between tdTomato and GFP in the Arc from double-transgenic P2rx4 tdTomato and POMC GFP reporter mice. $\boldsymbol{B}$, Images of fluorescent GFP-positive neurons in live slices from POMC GFP mice that were targeted for mIPSC recording in whole-cell mode. $C$, Schematic representation of the experimental strategy: tdTomato-positive neurons send GABAergic projections onto POMC neurons. We recorded mIPSCs from POMC GFP neurons and applied ATP locally via a puffer. $D$, Representative traces of mIPSCs recorded from POMC GFP neurons in response to five consecutive 20 s applications of $100 \mu \mathrm{m}$ ATP or aCSF. The mIPSCs were abolished by $10 \mu \mathrm{m}$ bicucculline. E, Plots of the average frequency and amplitude of mIPSCS over time from experiments, such as those in $\mathbf{D}$. F, Cumulative probability plots of mIPSC interevent interval and amplitude during applications of aCSF and ATP from the experiments shown in $\boldsymbol{E}$.

and other receptors (Tóth and McBain, 2000; Pelkey and McBain, 2007, 2008).

We could not reliably use ivermectin as a diagnostic of P2X4 receptors (Khakh et al., 1999) in our brain slice experiments because this allosteric modulator also potently modulates $\mathrm{GABA}_{\mathrm{A}}$ receptors (Krůsek and Zemková, 1994; Zemková et al., 2014) that mediate the mIPSCs we studied. We found that ivermectin applications evoked inward currents in POMC neurons (data not shown), most likely by 
A
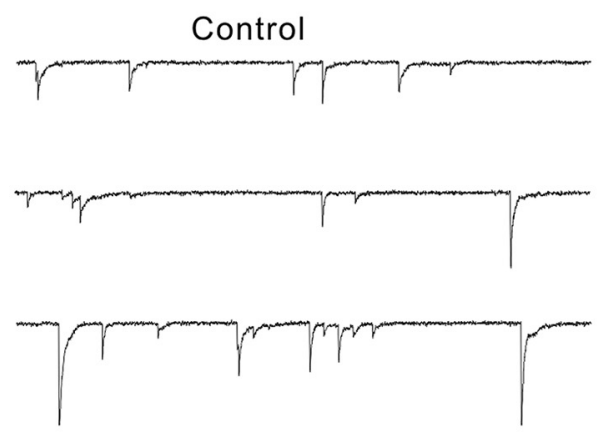

B

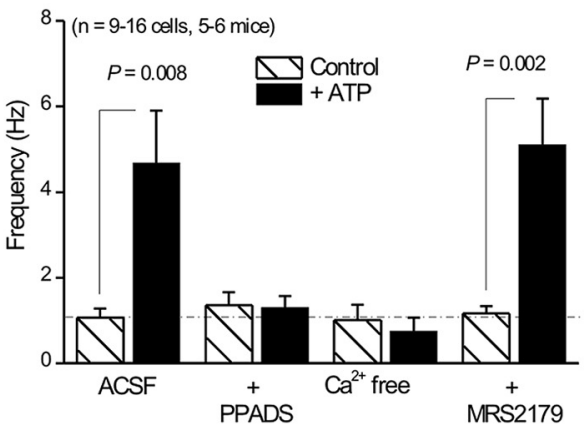

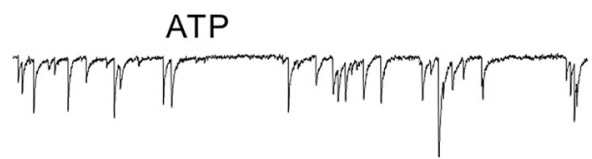
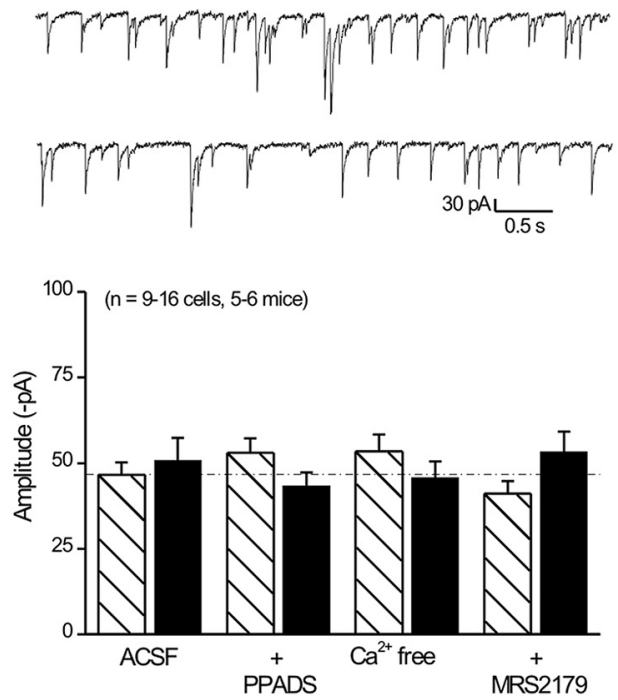

C $100 \mu \mathrm{MATP}$
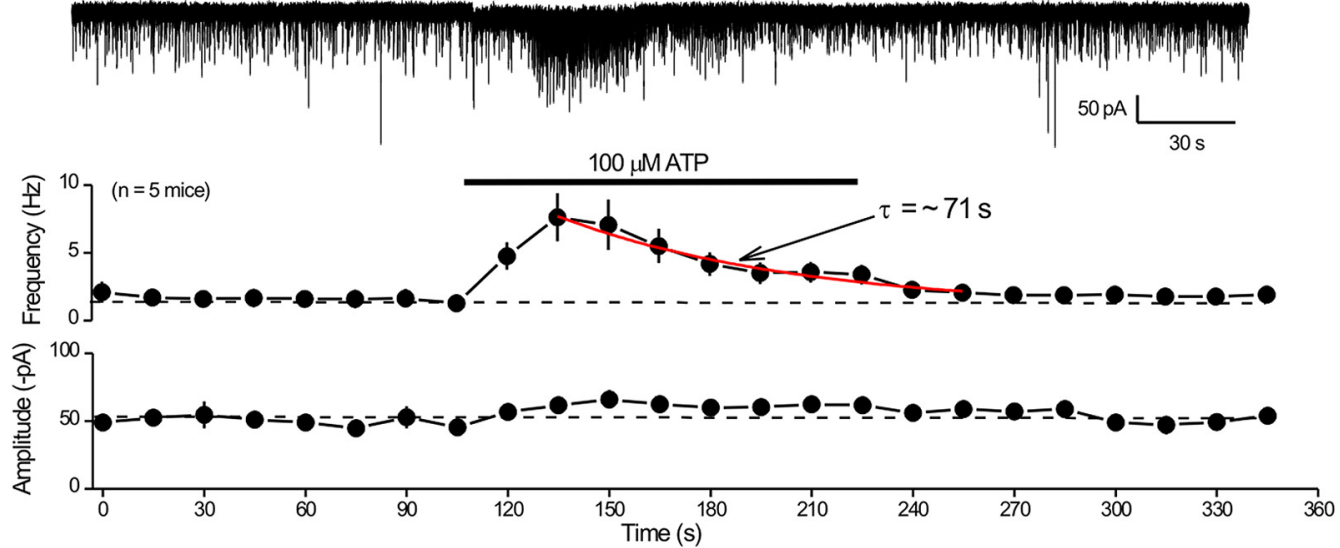

D
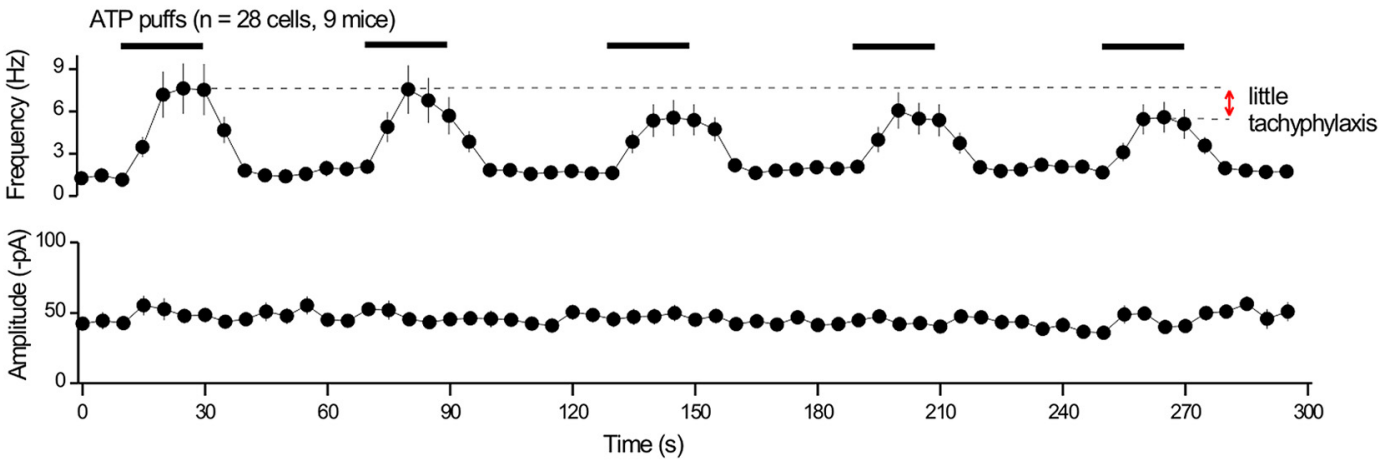

Figure 7. Properties of ATP-evoked presynaptic mIPSC facilitation onto POMC neurons. $\boldsymbol{A}$, Representative traces of mIPSCs before and during ATP applications. There is a clear increase in frequency with no change in amplitude. $\boldsymbol{B}$, Histograms summarize experiments where the ATP effect was evaluated under the indicated conditions. For these experiments, we used $10 \mu \mathrm{m}$ PPADS, nominally $\mathrm{Ca}^{2+}$ free solutions, and $30 \mu \mathrm{m}$ MRS-2179. C, Representative trace of mIPSCs during a prolonged $2 \mathrm{~min} 100 \mu \mathrm{m}$ ATP application. Bottom, Average mIPSC frequency and amplitude during the recording before, during, and after ATP. D. Average frequency and amplitude of mIPSCs in response to five consecutive 20 s applications of $100 \mu \mathrm{M}$ ATP or aCSF. The fifth application of ATP showed little tachyphylaxis compared with the first application.

modulating somatic $\mathrm{GABA}_{\mathrm{A}}$ receptors. This led to a decrease in whole-cell recording quality; thus, in the context of the experiments reported here that rely on reliable measurements of mIPSCs, ivermectin was not useful to identify $\mathrm{P} 2 \mathrm{X} 4$ receptors.
Regulation of the P2X4-mediated effect on presynaptic GABA release by food deprivation and a satiety-related hormone It is known that AgRP-NPY neurons drive food-seeking during hunger states (Atasoy et al., 2012), prompting us to evaluate 
Table 3. Comparison of presynaptic effects evoked by different ATP congeners during recordings from POMC neurons in $\mathrm{Arc}^{a}$

\begin{tabular}{|c|c|c|c|c|c|c|c|}
\hline & \multicolumn{2}{|c|}{ Frequency (Hz) } & \multirow[b]{2}{*}{$p$} & \multicolumn{2}{|c|}{ Amplitude (-pA) } & \multirow[b]{2}{*}{$p$} & \multirow[b]{2}{*}{$n$} \\
\hline & Control & + Agonist & & Control & + Agonist & & \\
\hline ATP & $2.46 \pm 0.72$ & $11.74 \pm 3.15$ & 0.009 & $63.4 \pm 6.5$ & $74.6 \pm 7.3$ & 0.13 & 14 \\
\hline ATP $\gamma S$ & $3.26 \pm 1.17$ & $5.90 \pm 1.65$ & 0.001 & $70.2 \pm 8.2$ & $74.1 \pm 7.1$ & 0.40 & 14 \\
\hline BzATP & $3.69 \pm 2.26$ & $3.38 \pm 1.96$ & 0.43 & $59.4 \pm 12.1$ & $57.9 \pm 9.0$ & 0.84 & 6 \\
\hline$\alpha, \beta$ meATP & $1.50 \pm 1.10$ & $1.10 \pm 0.31$ & 0.39 & $48.4 \pm 4.0$ & $47.7 \pm 5.2$ & 0.81 & 7 \\
\hline
\end{tabular}

${ }^{a}$ All the putative agonists were identically applied via a local puffer positioned near the neuron that was being recorded by the whole-cell voltage-clamp method.

whether presynaptic $\mathrm{P} 2 \mathrm{X} 4$ receptor responses on the terminals of NPY-AgRP neurons onto POMC neurons are dynamically regulated by metabolic state. In normally fed mice, the mIPSC frequency recorded from POMC neurons was significantly increased by ATP $(0.9 \pm 0.2 \mathrm{~Hz}$ before ATP application, $6.4 \pm 1.0$ $\mathrm{Hz}$ during ATP application, $p<0.001 ; n=9$ mice; Fig. 9A). In fasted mice, mIPSC frequency recorded from POMC neurons was also increased by ATP $(1.2 \pm 0.3 \mathrm{~Hz}$ before ATP application, $3.8 \pm 0.7 \mathrm{~Hz}$ during ATP application, $p<0.001 ; n=10$ mice; Fig. $9 A)$. However, the increase of mIPSC frequency was significantly diminished compared with normally fed mice $(6.4 \pm 1.0 \mathrm{~Hz}$ in normal fed mice, $3.8 \pm 0.7 \mathrm{~Hz}$ in fasted mice, $p=0.037 ; n=10$ mice; Fig. 9A). In many settings, leptin, a satiety hormone, regulates energy homeostasis by inhibiting hunger (Friedman and Halaas, 1998). We next tested whether leptin could reverse the decreased ATP responses observed as a consequence of food deprivation in fasted mice. In accord, mIPSC frequency during ATP application from fasted mice with leptin injected $3 \mathrm{~h}$ before brain slicing was not significantly different from that of normally fed mice $(6.4 \pm 1.0 \mathrm{~Hz}$ in normally fed mice, $5.8 \pm 0.8 \mathrm{~Hz}$ in fasted mice with leptin injection, $p=0.645$; Fig. $9 A$ ), indicating that leptin reversed the effect of fasting on the ATP-evoked GABA release facilitation. MIPSC amplitudes were not significantly altered by ATP in any of these conditions (normally fed, fasted, or fasted plus leptin; Fig. 9B).

We next determined whether the metabolic state also regulated the expression of tdTomato in P2rx4 tdTomato mice (Fig. 9C-E), as would be expected if $\mathrm{P} 2 \mathrm{X} 4$ gene expression were regulated by food deprivation. tdTomato expression levels in neurons located $<200 \mu \mathrm{m}$ away from medial eminence, and of tanycytes on the border of the third ventricle, were measured in normally fed mice, fasted mice, and fasted mice injected with leptin (Fig. 9C-E). In neurons and tanycytes, fasting significantly reduced tdTomato expression, which is consistent with reduced presynaptic P2X4 responses (Fig. 9A, B). Moreover, there was a trend for leptin to reverse the effect of fasting on tdTomato expression in neurons and tanycytes (Fig. 9D,E). This effect did not reach statistical significance for neurons but was significant for tanycytes (Fig. 9D,E). Together, the electrophysiological and imaging studies suggest that $\mathrm{P} 2 \mathrm{X} 4$ receptor expression and function are regulated by metabolic state (fasting and a satiety related hormone).

\section{Are $\mathrm{P} 2 \mathrm{X} 4$ receptors involved in the control of feeding?}

Because ATP increased GABA release from axon terminals of AgRPNPY neurons onto POMC neurons, we wondered whether this mechanism could affect feeding in vivo. We infused $3 \mathrm{~mm}$ ATP in vivo via guide cannulae implanted into the Arc and then measured food intake for $1 \mathrm{~h}$ after delivery (Fig. 10A,B). To ensure correct positioning, cannulae locations were verified in fixed brain sections after the experiments (Fig. 10A). In addition, we infused ghrelin as a positive control because intra-Arc injection of ghrelin significantly increases food intake during the light period (Yang et al., 2015). We confirmed that intra-Arc injection of $0.7 \mathrm{~mm}$ ghrelin increased food intake ( $86 \pm 42 \mathrm{mg}$ for vehicle control, $396 \pm 37 \mathrm{mg}$ for ghrelin, $p<$ 0.0001; Fig. 10B). However, infusion of ATP or ATP $\gamma S$ (3 mM) did not affect food intake (Fig. 10B), even when potentially confounding P2Y and adenosine receptors were blocked with MRS2179 and DPCPX, respectively, as a precaution (1 mM; Fig. 10B). We next tested whether P2X4 knock-out mice displayed phenotypes that may indicate altered feeding. Thus, we measured body weight, body length, gonadal and perirenal fat, heart and kidney weight, and the loss and gain in body weight during fasting and refeeding that may reveal roles for P2X4 receptors in the regulation of feeding behaviors. In this variety of well-established metrics of feeding, we found no differences between wild-type and P2X4 knock-out mice (Fig. 10C-G). Hence, our experiments provide ample evidence for presynaptic $\mathrm{P} 2 \mathrm{X} 4$ receptor-mediated facilitation of GABA release probability from AgRP-NPY neurons onto POMC neurons, but disappointingly no evidence that this mechanism is involved in the regulation of food intake on the basis of available whole-body P2X4 knock-out mice.

\section{Discussion}

There are four main findings from this study. First, we made and characterized a germline BAC transgenic mouse that expresses tdTomato fluorescent proteins from the P2rx4 locus. These mice were backcrossed with $\mathrm{C} 57 \mathrm{BL} / 6 \mathrm{~N}$ mice. They reproduced as expected, displayed no overt phenotypic problems, but importantly expressed tdTomato in sparse populations of cells throughout the brain. Second, the pattern of tdTomato expression in the brain matched that expected from seminal P2X4 mRNA distribution studies (Buell et al., 1996; Collo et al., 1996) and as part of the Allen Brain Atlas database (Table 1). This suggests that P2rx4 tdTomato mice provide a faithful readout of P2X4 mRNAexpressing cells. Third, tdTomato expression levels were increased markedly in microglia following in vivo LPS injections to trigger microglial reactivity, implying that tdTomato expression could be used as a measure of P2X4 gene regulation and microglial activation per se. Fourth, we found abundant tdTomato expression in the Arc; and by studying genetic crosses and functional responses from both AgRP-NPY and POMC neurons, we show that presynaptic $\mathrm{P} 2 \mathrm{X} 4$ receptors regulate $\mathrm{GABA}$ release in a manner that is calcium-dependent and regulated by metabolic state. These findings may portend hitherto unanticipated roles of $\mathrm{P} 2 \mathrm{X} 4$ receptors and ATP signaling in the regulation of feeding, as has been recently shown for UDP-glucose P2Y receptor signaling (Steculorum et al., 2015). Overall, our study provides a much needed and well-characterized transgenic mouse model to study $\mathrm{P} 2 \mathrm{X} 4$ receptor-expressing cells in the brain. We consider additional relevant points below.

We used a P2X4 BAC to drive tdTomato expression under the control of $\mathrm{P} 2 \mathrm{X} 4$ receptor gene's regulatory elements. In the modified BAC, intact 5' and 3' flanking regions ensure faithful representation of endogenous P2X4 gene expression, which was corroborated by the empirical observations that tdTomato expression was consistent with the P2X4 mRNA distribution (Table 1) and upregulated in microglia following LPS injections (Tsuda et al., 2003; Ulmann et al., 2008, 2010, 2013). A potential shortcoming of the BAC transgenic method, however, is that the strategy may introduce copies of other genes within the BAC. In the mouse genome, $\mathrm{P} 2 \mathrm{X} 4$ and $\mathrm{P} 2 \mathrm{X} 7$ receptor genes are adjacent, and the P2X4 BAC we used also carries a copy of the P2X7 gene. However, electrophysiological recordings from tdTomatopositive neurons did not show any somatic ATP-evoked currents that may indicate aberrant $\mathrm{P} 2 \mathrm{X} 7$ expression in relation to wild- 
type mice, and the $\mathrm{P} 2 \mathrm{X} 7$ receptor agonist BzATP did not increase mIPSC frequency onto POMC neurons. Therefore, we found no evidence for aberrant expression of $\mathrm{P} 2 \mathrm{X} 7$ receptors in $\mathrm{P} 2 \mathrm{rx} 4 \mathrm{tdT}$ tomato mice. We suggest this is because the $\mathrm{P} 2 \mathrm{X} 7$ gene carries only a short $5^{\prime}$ region in the $\mathrm{BAC}$ we used to generate P2rx4 tdTomato mice.

The availability of P2rx4 tdTomato mice provided an opportunity to identify and characterize P2X4-expressing cells in the brain, which has proven challenging in past work (see Introduction). Overall, the pattern of tdTomato expression in the olfactory epithelium and brain was almost identical to past studies of P2X4 mRNA distribution (Buell et al., 1996; Collo et al., 1996; Lein et al., 2007); and broadly speaking, the sparse labeling observed in the locus ceruleus, cortex, hippocampus, and cerebellum matches the reported P2X functional responses that have been described in these areas (Shen and North, 1993; North, 2002; Khakh et al., 2003; Sim et al., 2006; Pankratov et al., 2007; Baxter et al., 2011). Additionally, increased microglial tdTomato expression following LPS injections was expected, implying that P2rx4 tdTomato reporter mice may provide an optical readout of microglia activation and of $\mathrm{P} 2 \mathrm{X} 4$ gene regulation in mouse models of neuropathy, epilepsy, pain, and alcohol addiction (Tsuda et al., 2003; Ulmann et al., 2010, 2013; Gofman et al., 2014); that is, they may be of general value in the study of microglia-associated disease processes (Salter and Beggs, 2014). Furthermore, the abundant expression of tdTomato in AgRP-NPY neurons is consistent with recently published RNAseq data from Arc that show high levels of P2X4 mRNAs in AgRP-NPY neurons (Henry et al., 2015). Based on these findings, we feel confident that P2rx4 tdTomato mice could be used to study P2X4-expressing cells in the brain and periphery (especially in the Arc). We note, however, that the BAC method leaves open the possibility that cells expressing very few $\mathrm{P} 2 \mathrm{X} 4$ receptors may not express sufficient tdTomato for detection. Hence, the positive result of tdTomato expression in cells is the most readily interpretable, and cells that have no detectable tdTomato could conceivably still express few P2X4 transcripts or receptors (e.g., the striatum). Additional methods are needed to study these cells, and our findings need to be interpreted with this cautionary note in mind. For example, breeding the reporter mice to homozygosity may conceivably boost expression of tdTomato to detectable levels in some brain areas.
A
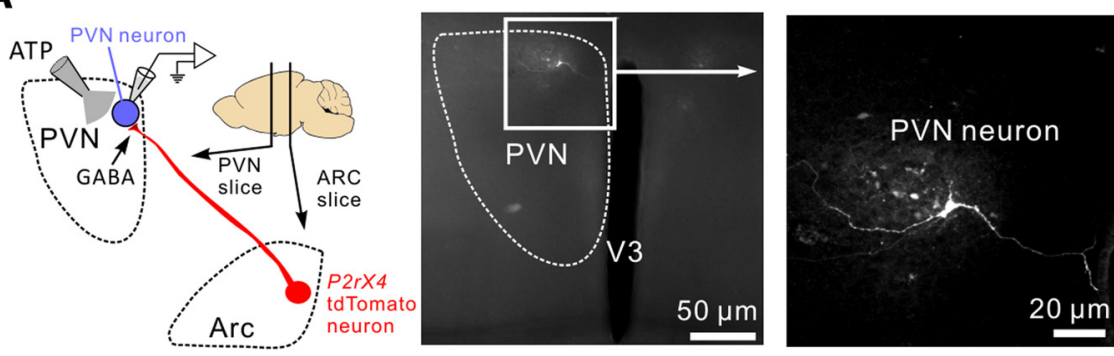

B

$100 \mu \mathrm{MATP} \quad 10 / 31$ cells
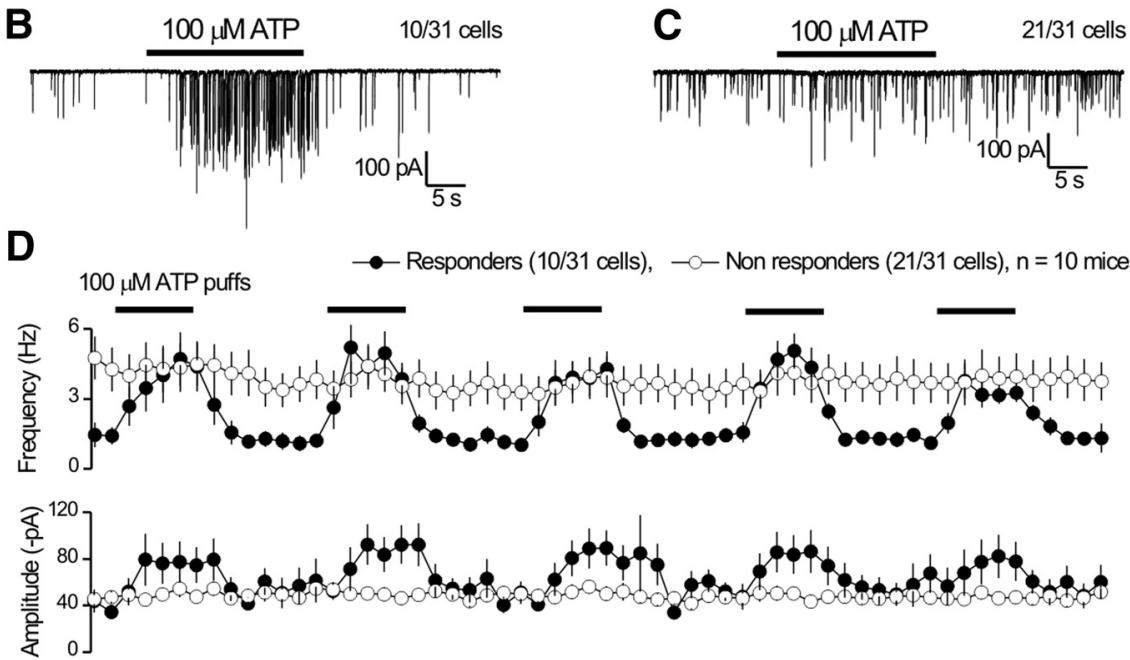

E
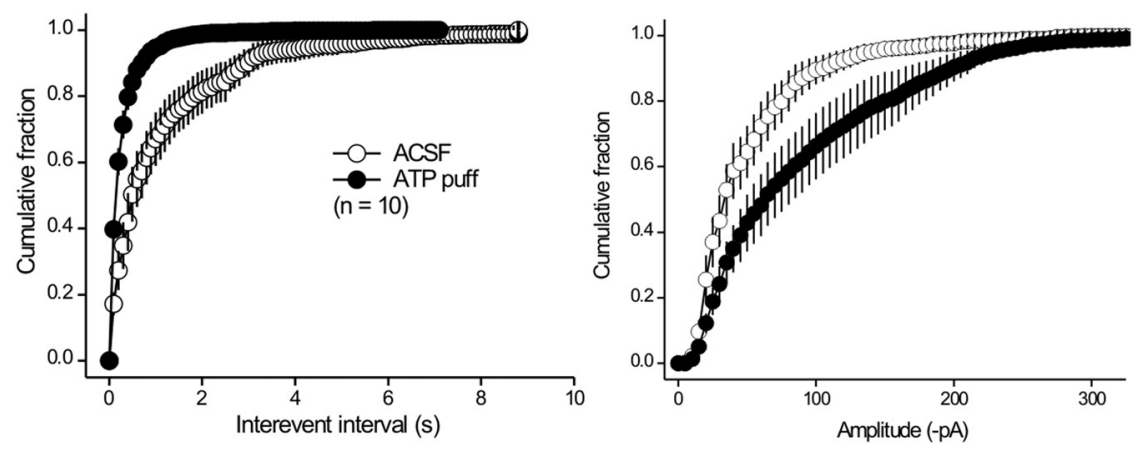

$\mathbf{F}$
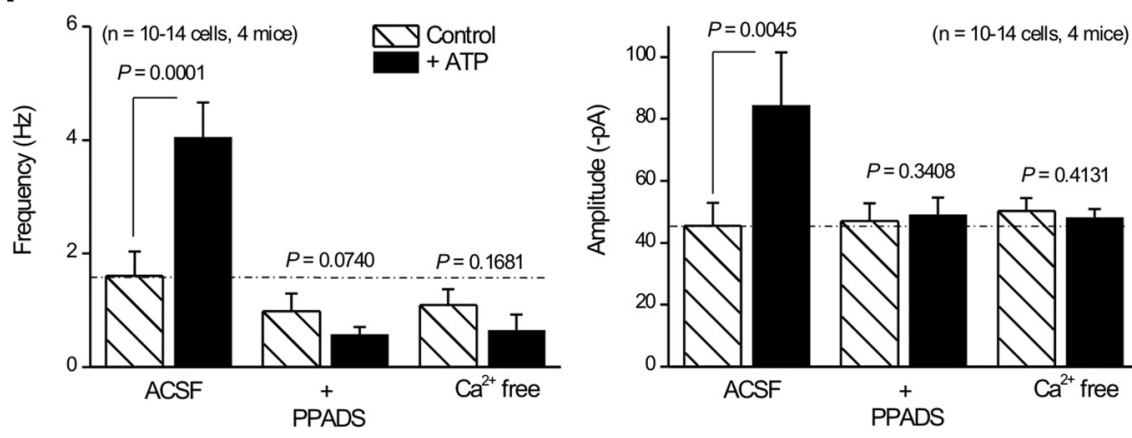

Figure 8. Properties of ATP-evoked presynaptic mIPSC facilitation onto PVN neurons. $\boldsymbol{A}$, Schematic of the GABAergic projection of tdTomato-positive neurons from the Arc to the PVN. The PVN neurons were targeted for whole-cell recording of mIPSCs. Right panels, Confocal images of a PVN neuron filled with biocytin via the patch pipette. $\boldsymbol{B}$, Representative trace of mIPSCs recorded from a PVN neuron responding to $100 \mu \mathrm{M}$ ATP. C, Representative trace of mIPSCs recorded from a PVN neuron that did not respond to 100 $\mu M$ ATP. $D$, Average frequency and amplitudes of mIPSCs recorded from responding and nonresponding PVN neurons as shown in $\boldsymbol{B}, \boldsymbol{C}$. $\boldsymbol{E}$, Cumulative probability plots of mIPSC interevent intervals and amplitudes recorded from PVN neurons that responded during applications of ATP. $\boldsymbol{F}$, Histograms represent mIPSC frequency and amplitude from PVN neurons responding to ATP under various conditions, including control, $10 \mu \mathrm{M}$ PPADS, and nominally $\mathrm{Ca}^{2+}$ free solutions. 
A Normally fed mice

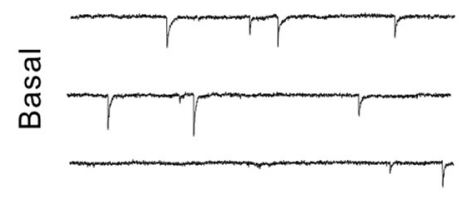

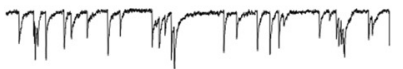

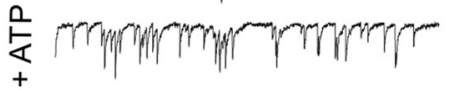

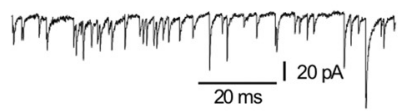

Fasted mice
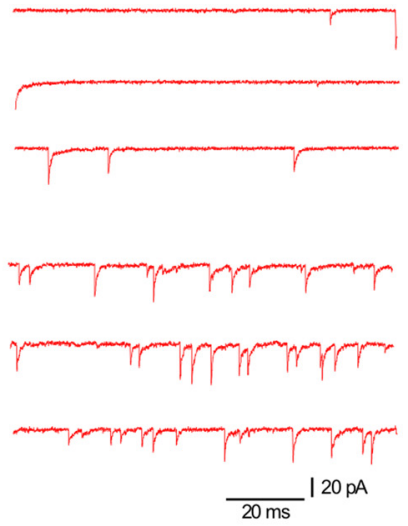

Fasted mice + leptin

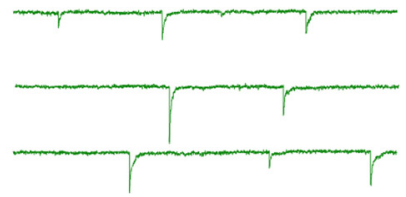

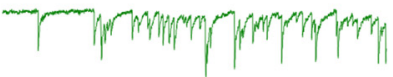

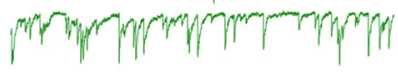

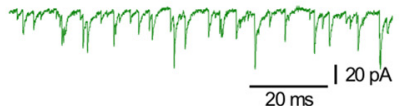

B

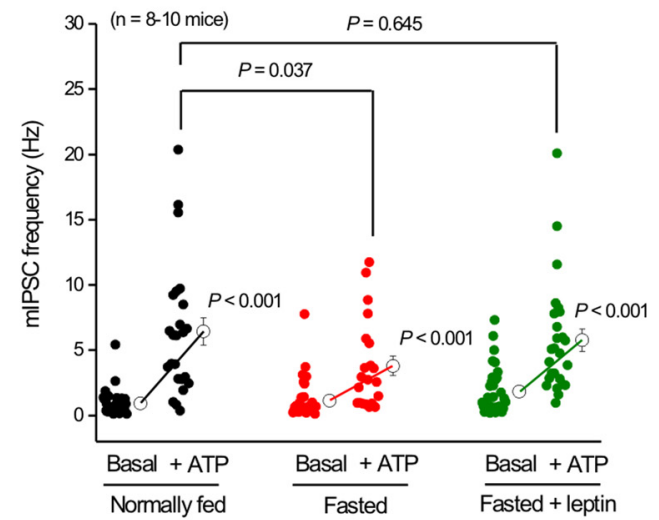

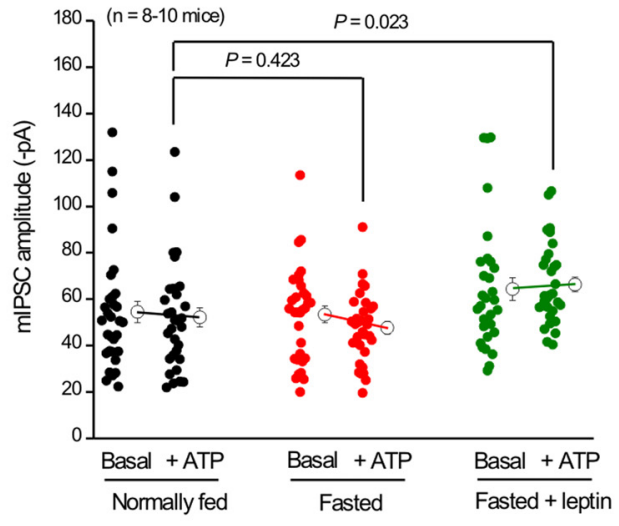

Fasted

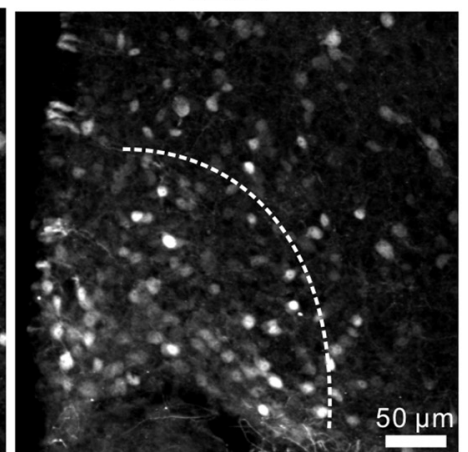

Fasted + leptin

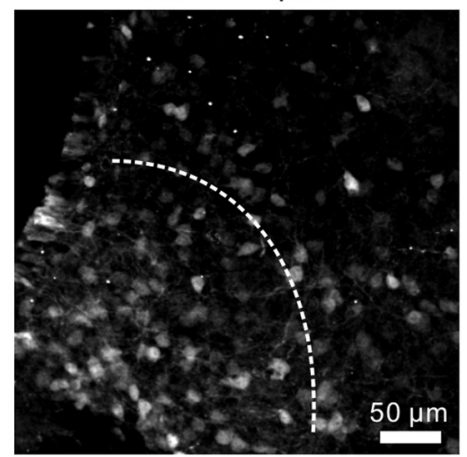

$\mathbf{E}$

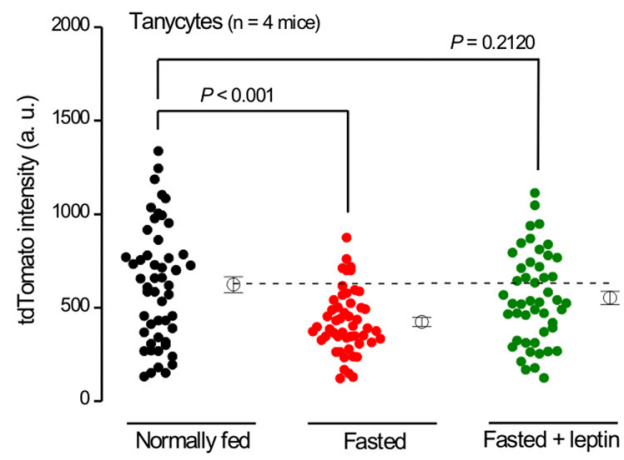

Figure 9. Regulation of ATP-evoked mIPSC facilitation onto POMC neurons and tdTomato expression in AgRP-NPY neurons by metabolic state. $A$, Representative traces of mIPSCs before and during ATP applications recorded from POMC neurons in normally fed mice, fasted mice, and fasted mice injected with leptin $(1 \mu \mathrm{g} / \mathrm{g}) 3 \mathrm{~h}$ before the experiments. $\boldsymbol{B}$, Summary of mIPSC frequency and amplitude from experiments, such as those in $A$. C, Representative tdTomato IHC images for Arc from normally fed mice, fasted mice, and fasted mice injected with leptin. Dotted lines indicate the area in which tdTomato intensity was measured. $\boldsymbol{D}, \boldsymbol{E}$, tdTomato intensity in neurons $(\boldsymbol{D})$ and tanycytes $(\boldsymbol{C})$ from experiments, such as those shown in $\boldsymbol{C}$. 


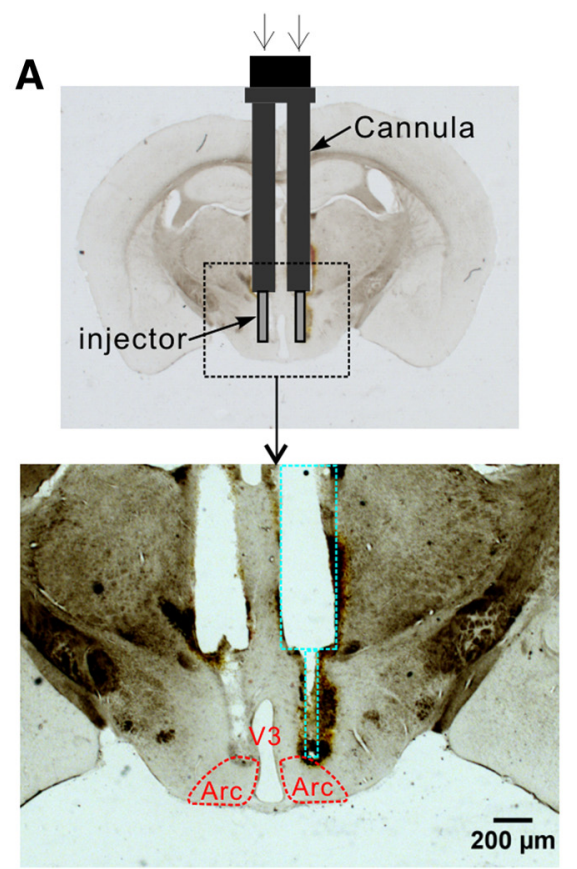

B
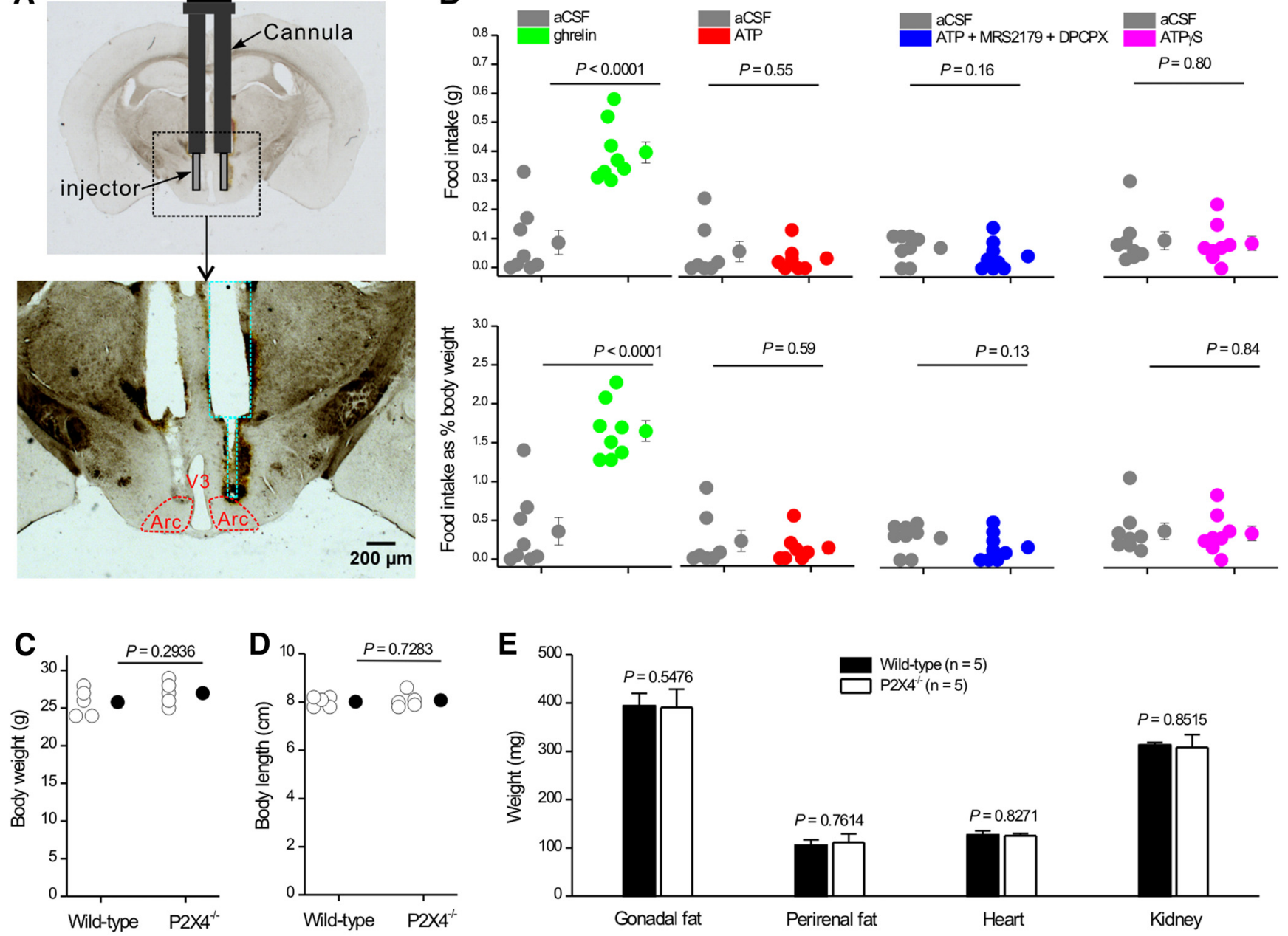

Wild-type $(n=5)$

$P 2 \times 4^{-/ 2}(n=5)$

$\mathbf{F}$

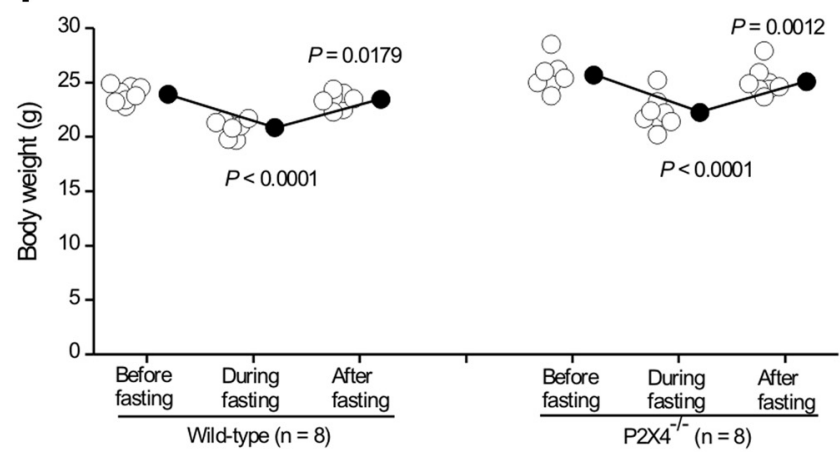

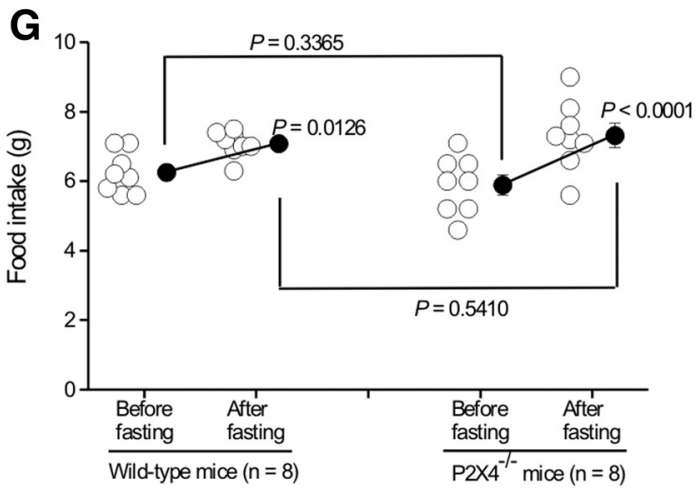

Figure 10. Assessment of feeding in response to ATP and in P2X4 knock-out mice. A, Schematic illustrating the location of the guide cannula and injector for intra-Arc ATP and ghrelin injections. Top, Bilateral guide cannula and injectors projecting out of the cannula implanted in the mouse brain. Bottom, Track of the bilateral cannula with injectors, as marked by green dotted lines in relation to Arc (red). B, Food intake (top graphs) or food intake as a percentage of body weight (bottom graphs) during a $1 \mathrm{~h}$ period after bilateral delivery of $500 \mathrm{nl}$ ghrelin $(0.7 \mathrm{~mm})$, ATP $(3 \mathrm{~mm})$, ATP ( $3 \mathrm{~mm}$ ) plus MRS2179 (1 mM), and DPCPX (1 mM) or ATP $\gamma S$ (3 mM). C, D, Body weight ( $($ ) and length (D) of 2-month-old wild-type and P2X4 knock-out mice. $\boldsymbol{E}$, Plot of gonadal fat, perirenal fat, heart, and kidney weights from 2-month-old wild-type and P2X4 knock-out mice. F, Body weights of wild-type and P2X4 knock-out mice before, during, and after fasting. G, Plot of food intake for wild-type and P2X4 knock-out mice before and after fasting.

We identified tdTomato-expressing neurons in Arc as AgRPNPY neurons. However, there were few, if any, functional P2X4 receptors on the somata of Arc neurons; there was also no evidence for fast ATP synaptic transmission in this nucleus. These observations are similar to findings in other, but not all, brain areas and suggest that P2X4 receptors are trafficked to presynap- tic terminals (Khakh and North, 2012). By exploiting these insights, we provide evidence that GABA release probability onto POMC neurons from AgRP-NPY neuron terminals was increased by ATP acting on presynaptic $\mathrm{P} 2 \mathrm{X} 4$ receptors in a manner that was strongly modulated by metabolic state and was due to calcium fluxes. Presynaptic expression of P2X4 receptors was 
first suggested soon after the receptors were cloned (Lê et al., 1998); our data extend these insights to the Arc with functional evaluations. However, despite the known association of AgRPNPY neurons with regulation of food intake, we failed to find a $\mathrm{P} 2 \mathrm{X} 4$-associated feeding phenotype in vivo under the experimental conditions we tested. We report these data in Figure 10 and discuss relevant considerations below.

In future studies, it would be valuable to map additional inputs to both AgRP-NPY and POMC neurons and explore expression of P2X4 and potentially other $\mathrm{P} 2 \mathrm{X}$ and $\mathrm{P} 2 \mathrm{Y}$ receptors in these pathways (Pollatzek et al., 2016). Such detailed understanding of ATP effects within the Arc is needed to form specific hypotheses on the potential roles that ATP signaling may play within this and other hypothalamic nuclei (Stojilkovic, 2009). Thus, although ATP facilitation of GABA release onto POMC neurons would be expected to inhibit POMC neurons and drive feeding, we failed to find any evidence that ATP regulated feeding either when ATP was applied within the Arc in vivo or when P2X4 receptors were genetically deleted. A more detailed understanding of ATP and GABA signaling in the Arc is needed to understand these differences. For example, it is possible that the ATPevoked GABA synaptic events are not inhibitory in POMC neurons, which may explain the lack of in vivo phenotype in relation to feeding (as far as we know, the $\mathrm{Cl}^{-}$equilibrium potential in POMC neuron dendrites in vivo is unknown). Another possibility is that the POMC neurons that are presynaptically facilitated by P2X4 do not regulate feeding. Although the present feeding evaluations were done in males, in females a population of POMC neurons projects to the medial preoptic area to regulate sexual receptivity (Mills et al., 2004). Indeed, GABA has been implicated in the activity of the AgRP-NPY-to-POMC microcircuit regulating this behavior (Sinchak et al., 2013). Moreover, the function of presynaptic $\mathrm{P} 2 \mathrm{X} 4$ receptors may be to mediate homeostatic plasticity and/or synaptic scaling and thus not be directly involved in triggering POMC action potential firing. Such roles would be consistent with the proposed functions of miniature synaptic events (Kavalali, 2015) and with recent studies on postsynaptic P2X receptors in the hippocampus (Sim et al., 2006; Baxter et al., 2011; Pougnet et al., 2014). Future studies could explore the role of $\mathrm{P} 2 \mathrm{X} 4$ receptors in presynaptic forms of synaptic plasticity in Arc. Another possibility is that Arc expresses additional receptors, such as postsynaptic metabotropic P2Y receptors, which are electrophysiologically silent in our wholecell recordings but regulate POMC neurons nonetheless and thus mask the in vivo effects of ATP. Selective P2X4 agonists, which currently do not exist, are needed to address this possibility. Finally, perhaps the simplest explanation for the lack of feeding phenotype in the P2X4 knock-out mice is that they display compensation during the course of development such that feeding behavior was largely normal in adulthood. From an evolutionary standpoint, feeding is a very robust behavior, and this could explain why past work with NPY and AgRP single- and doubleknock-out mice also showed no feeding phenotype (Qian et al., 2002), even though both NPY and AgRP are critical regulators of feeding and Arc neuron function (Ollmann et al., 1997; Levine et al., 2004). Hence, roles for $\mathrm{P} 2 \mathrm{X} 4$ receptors in feeding need to be further explored by conditional P2X4 receptor deletion within AgRP-NPY neurons in fully developed adult mice, and with selective P2X4 agonists and antagonists when they become available. Our findings provide the basis for these future studies to comprehensively explore $\mathrm{P} 2 \mathrm{X} 4$ receptor signaling and feeding.

Most importantly, our studies provide thoroughly characterized tdTomato reporter mice with which to study P2X4 receptor-expressing cells throughout the body, including within the nervous system.

\section{References}

Ase AR, Honson NS, Zaghdane H, Pfeifer TA, Séguéla P (2015) Identification and characterization of a selective allosteric antagonist of human P2X4 receptor channels. Mol Pharmacol 87:606-616. CrossRef Medline

Atasoy D, Betley JN, Su HH, Sternson SM (2012) Deconstruction of a neural circuit for hunger. Nature 488:172-177. CrossRef Medline

Baxter AW, Choi SJ, Sim JA, North RA (2011) Role of P2X4 receptors in synaptic strengthening in mouse CA1 hippocampal neurons. Eur J Neurosci 34:213-220. CrossRef Medline

Besser S, Sicker M, Marx G, Winkler U, Eulenburg V, Hülsmann S, Hirrlinger J (2015) A transgenic mouse line expressing the red fluorescent protein tdTomato in GABAergic neurons. PLoS One 10:e0129934. CrossRef Medline

Bo X, Zhang Y, Nassar M, Burnstock G, Schoepfer R (1995) A P2X purinoceptor cDNA conferring a novel pharmacological profile. FEBS Lett 375: 129-133. CrossRef Medline

Bobanović LK, Royle SJ, Murrell-Lagnado RD (2002) P2X receptor trafficking in neurons is subunit specific. J Neurosci 22:4814-4824. Medline

Bortolato M, Yardley MM, Khoja S, Godar SC, Asatryan L, Finn DA, Alkana RL, Louie SG, Davies DL (2013) Pharmacological insights into the role of P2X4 receptors in behavioural regulation: lessons from ivermectin. Int J Neuropsychopharmacol 16:1059-1070. CrossRef Medline

Bowler JW, Bailey RJ, North RA, Surprenant A (2003) P2X4, P2Y1 and P2Y2 receptors on rat alveolar macrophages. Br J Pharmacol 140:567575. CrossRef Medline

Bowser DN, Khakh BS (2004) ATP excites interneurons and astrocytes to increase synaptic inhibtion in neuronal networks. J Neurosci 24: 8606-8620. CrossRef Medline

Buell G, Lewis C, Collo G, North RA, Surprenant A (1996) An antagonistinsensitive P2X receptor expressed in epithelia and brain. EMBO J 15: 55-62. Medline

Burnstock G (1972) Purinergic nerves. Pharmacol Rev 24:509-581. Medline

Coddou C, Yan Z, Obsil T, Huidobro-Toro JP, Stojilkovic SS (2011) Activation and regulation of purinergic $\mathrm{P} 2 \mathrm{X}$ receptor channels. Pharmacol Rev 63:641-683. CrossRef Medline

Collo G, North RA, Kawashima E, Merlo-Pich E, Neidhart S, Surprenant A, Buell G (1996) Cloning of $\mathrm{P} 2 \mathrm{X}_{5}$ and $\mathrm{P} 2 \mathrm{X}_{6}$ receptors and the distribution and properties of an extended family of ATP-gated ion channels. J Neurosci 16:2495-2507. Medline

Coull JA, Beggs S, Boudreau D, Boivin D, Tsuda M, Inoue K, Gravel C, Salter MW, De Koninck Y (2005) BDNF from microglia causes the shift in neuronal anion gradient underlying neuropathic pain. Nature 438:10171021. CrossRef Medline

Cowley MA, Smart JL, Rubinstein M, Cerdán MG, Diano S, Horvath TL, Cone RD, Low MJ (2001) Leptin activates anorexigenic POMC neurons through a neural network in the arcuate nucleus. Nature 411:480-484. CrossRef Medline

Egan TM, Khakh BS (2004) Contribution of calcium ions to P2X channel responses. J Neurosci 24:3413-3420. CrossRef Medline

Ferrini F, Trang T, Mattioli TA, Laffray S, Del'Guidice T, Lorenzo LE, Castonguay A, Doyon N, Zhang W, Godin AG, Mohr D, Beggs S, Vandal K, Beaulieu JM, Cahill CM, Salter MW, De Koninck Y (2013) Morphine hyperalgesia gated through microglia-mediated disruption of neuronal $\mathrm{Cl}^{-}$homeostasis. Nat Neurosci 16:183-192. CrossRef Medline

Frayling C, Britton R, Dale N (2011) ATP-mediated glucosensing by hypothalamic tanycytes. J Physiol 589:2275-2286. CrossRef Medline

Friedman JM, Halaas JL (1998) Leptin and the regulation of body weight in mammals. Nature 395:763-770. CrossRef Medline

Garfield AS, Li C, Madara JC, Shah BP, Webber E, Steger JS, Campbell JN, Gavrilova O, Lee CE, Olson DP, Elmquist JK, Tannous BA, Krashes MJ, Lowell BB (2015) A neural basis for melanocortin-4 receptor-regulated appetite. Nat Neurosci 18:863-871. CrossRef Medline

Gee JM, Smith NA, Fernandez FR, Economo MN, Brunert D, Rothermel M, Morris SC, Talbot A, Palumbos S, Ichida JM, Shepherd JD, West PJ, Wachowiak M, Capecchi MR, Wilcox KS, White JA, Tvrdik P (2014) Imaging activity in neurons and glia with a Polr2a-based and credependent GCaMP5G-IRES-tdTomato reporter mouse. Neuron 83: 1058-1072. CrossRef Medline 
Gofman L, Cenna JM, Potula R (2014) P2X4 receptor regulates alcoholinduced responses in microglia. J Neuroimmune Pharmacol 9:668-678. CrossRef Medline

Gonzales EB, Kawate T, Gouaux E (2009) Pore architecture and ion sites in acid-sensing ion channels and P2X receptors. Nature 460:599-604. CrossRef Medline

Gu JG, MacDermott AB (1997) Activation of ATP P2X receptors elicits glutamate release from sensory neuron synapses. Nature 389:749-753. CrossRef Medline

Habermacher C, Dunning K, Chataigneau T, Grutter T (2016) Molecular structure and function of P2X receptors. Neuropharmacology 104:18-30. CrossRef Medline

Hamby ME, Coppola G, Ao Y, Geschwind DH, Khakh BS, Sofroniew MV (2012) Inflammatory mediators alter the astrocyte transcriptome and calcium signaling elicited by multiple G-protein-coupled receptors. J Neurosci 32:14489-14510. CrossRef Medline

Hattori M, Gouaux E (2012) Molecular mechanism of ATP binding and ion channel activation in P2X receptors. Nature 485:207-212. CrossRef Medline

Haustein MD, Kracun S, Lu XH, Shih T, Jackson-Weaver O, Tong X, Xu J, Yang XW, O'Dell TJ, Marvin JS, Ellisman MH, Bushong EA, Looger LL, Khakh BS (2014) Conditions and constraints for astrocyte calcium signaling in the hippocampal mossy fiber pathway. Neuron 82:413-429. CrossRef Medline

Henry FE, Sugino K, Tozer A, Branco T, Sternson SM (2015) Cell typespecific transcriptomics of hypothalamic energy-sensing neuron responses to weight-loss. Elife 4:10.7554/eLife.09800. CrossRef Medline

Jiang R, Taly A, Grutter T (2013) Moving through the gate in ATP-activated P2X receptors. Trends Biochem Sci 38:20-29. CrossRef Medline

Jones CA, Chessell IP, Simon J, Barnard EA, Miller KJ, Michel AD, Humphrey PP (2000) Functional characterization of the P2X(4) receptor orthologues. Br J Pharmacol 129:388-394. CrossRef Medline

Kavalali ET (2015) The mechanisms and functions of spontaneous neurotransmitter release. Nat Rev Neurosci 16:5-16. CrossRef Medline

Kawate T, Michel JC, Birdsong WT, Gouaux E (2009) Crystal structure of the ATP-gated P2X(4) ion channel in the closed state. Nature 460:592598. CrossRef Medline

Khakh BS (2001) Molecular physiology of P2X receptors and ATP signalling at synapses. Nat Rev Neurosci 2:165-174. CrossRef Medline

Khakh BS, Henderson G (1998) ATP receptor-mediated enhancement of fast excitatory neurotransmitter release in the brain. Mol Pharmacol 54: 372-378. CrossRef Medline

Khakh BS, North RA (2006) P2X receptors as cell surface ATP sensors in health and disease. Nature 442:527-532. CrossRef Medline

Khakh BS, North RA (2012) Neuromodulation by extracellular ATP and P2X receptors in the CNS. Neuron 76:51-69. CrossRef Medline

Khakh BS, Proctor WR, Dunwiddie TV, Labarca C, Lester HA (1999) Allosteric control of gating and kinetics at $\mathrm{P} 2 \mathrm{X}_{4}$ receptor channels. J Neurosci 19:7289-7299. Medline

Khakh BS, Burnstock G, Kennedy C, King BF, North RA, Séguéla P, Voigt M, Humphrey PP (2001) International Union of Pharmacology: XXIV. Current status of the nomenclature and properties of P2X receptors and their subunits. Pharmacol Rev 53:107-118. Medline

Khakh BS, Gittermann D, Cockayne DA, Jones A (2003) ATP modulation of excitatory synapses onto interneurons. J Neurosci 23:7426-7437. Medline

Krůsek J, Zemková H (1994) Effect of ivermectin on gamma-aminobutyric acid-induced chloride currents in mouse hippocampal embryonic neurones. Eur J Pharmacol 259:121-128. CrossRef Medline

Langlet F (2014) Tanycytes: a gateway to the metabolic hypothalamus. J Neuroendocrinol 26:753-760. CrossRef Medline

Lê KT, Villeneuve P, Ramjaun AR, McPherson PS, Beaudet A, Séguéla P (1998) Sensory presynaptic and widespread somatodendritic immunolocalization of central ionotropic P2X ATP receptors. Neuroscience 83: 177-190. CrossRef Medline

Lein ES, Hawrylycz MJ, Ao N, Ayres M, Bensinger A, Bernard A, Boe AF, Boguski MS, Brockway KS, Byrnes EJ, Chen L, Chen L, Chen TM, Chin MC, Chong J, Crook BE, Czaplinska A, Dang CN, Datta S, Dee NR, et al. (2007) Genome-wide atlas of gene expression in the adult mouse brain. Nature 445:168-176. CrossRef Medline

Levine AS, Jewett DC, Cleary JP, Kotz CM, Billington CJ (2004) Our jour- ney with neuropeptide Y: effects on ingestive behaviors and energy expenditure. Peptides 25:505-510. CrossRef Medline

Miklavc P, Mair N, Wittekindt OH, Haller T, Dietl P, Felder E, Timmler M, Frick M (2011) Fusion-activated $\mathrm{Ca}^{2+}$ entry via vesicular P2X4 receptors promotes fusion pore opening and exocytotic content release in pneumocytes. Proc Natl Acad Sci U S A 108:14503-14508. CrossRef Medline

Miklavc P, Thompson KE, Frick M (2013) A new role for P2X receptors as modulators of lung surfactant secretion. Front Cell Neurosci 7:171. CrossRef Medline

Mills RH, Sohn RK, Micevych PE (2004) Estrogen-induced mu-opioid receptor internalization in the medial preoptic nucleus is mediated via neuropeptide $\mathrm{Y}-\mathrm{Y} 1$ receptor activation in the arcuate nucleus of female rats. J Neurosci 24:947-955. CrossRef Medline

Murrell-Lagnado RD, Qureshi OS (2008) Assembly and trafficking of P2X purinergic receptors (Review). Mol Membr Biol 25:321-331. CrossRef Medline

North RA (2002) Molecular physiology of P2X receptors. Physiol Rev 82: 1013-1067. CrossRef Medline

Ollmann MM, Wilson BD, Yang YK, Kerns JA, Chen Y, Gantz I, Barsh GS (1997) Antagonism of central melanocortin receptors in vitro and in vivo by agouti-related protein. Science 278:135-138. CrossRef Medline

Ostrovskaya O, Asatryan L, Wyatt L, Popova M, Li K, Peoples RW, Alkana RL, Davies DL (2011) Ethanol is a fast channel inhibitor of P2X4 receptors. J Pharmacol Exp Ther 337:171-179. CrossRef Medline

Pankratov Y, Lalo U, Verkhratsky A, North RA (2007) Quantal release of ATP in mouse cortex. J Gen Physiol 129:257-265. CrossRef Medline

Pelkey KA, McBain CJ (2007) Differential regulation at functionally divergent release sites along a common axon. Curr Opin Neurobiol 17: 366-373. CrossRef Medline

Pelkey KA, McBain CJ (2008) Target-cell-dependent plasticity within the mossy fibre-CA3 circuit reveals compartmentalized regulation of presynaptic function at divergent release sites. J Physiol 586:1495-1502. CrossRef Medline

Pollatzek E, Hitzel N, Ott D, Raisl K, Reuter B, Gerstberger R (2016) Functional expression of $\mathrm{P} 2$ purinoceptors in a primary neuroglial cell culture of the rat arcuate nucleus. Neuroscience 327:95-114. CrossRef Medline

Pougnet JT, Toulme E, Martinez A, Choquet D, Hosy E, Boué-Grabot E (2014) ATP P2X receptors downregulate AMPA receptor trafficking and postsynaptic efficacy in hippocampal neurons. Neuron 83:417-430. CrossRef Medline

Qian S, Chen H, Weingarth D, Trumbauer ME, Novi DE, Guan X, Yu H, Shen Z, Feng Y, Frazier E, Chen A, Camacho RE, Shearman LP, Gopal-Truter S, MacNeil DJ, Van der Ploeg LH, Marsh DJ (2002) Neither agouti-related protein nor neuropeptide $\mathrm{Y}$ is critically required for the regulation of energy homeostasis in mice. Mol Cell Biol 2:5027-5035. CrossRef Medline

Qureshi OS, Paramasivam A, Yu JC, Murrell-Lagnado RD (2007) Regulation of P2X4 receptors by lysosomal targeting, glycan protection and exocytosis. J Cell Sci 120:3838-3849. CrossRef Medline

Raouf R, Chabot-Doré AJ, Ase AR, Blais D, Séguéla P (2007) Differential regulation of microglial $\mathrm{P} 2 \mathrm{X} 4$ and $\mathrm{P} 2 \mathrm{X} 7$ ATP receptors following LPS-induced activation. Neuropharmacology 53:496-504. CrossRef Medline

Royle SJ, Murrell-Lagnado RD (2003) Constitutive cycling: a general mechanism to regulate cell surface proteins. Bioessays 25:39-46. CrossRef Medline

Royle SJ, Bobanović LK, Murrell-Lagnado RD (2002) Identification of a non-canonical tyrosine-based endocytic motif in an ionotropic receptor. J Biol Chem 277:35378-35385. CrossRef Medline

Royle SJ, Qureshi OS, Bobanović LK, Evans PR, Owen DJ, Murrell-Lagnado RD (2005) Non-canonical YXXGPhi endocytic motifs: recognition by AP2 and preferential utilization in P2X4 receptors. J Cell Sci 118:30733080. CrossRef Medline

Salter MW, Beggs S (2014) Sublime microglia: expanding roles for the guardians of the CNS. Cell 158:15-24. CrossRef Medline

Samways DS, Li Z, Egan TM (2014) Principles and properties of ion flow in P2X receptors. Front Cell Neurosci 8:6. CrossRef Medline

Séguéla P, Haghighi A, Soghomonian JJ, Cooper E (1996) A novel neuronal 
P2x ATP receptor ion channel with widespread distribution in the brain. J Neurosci 16:448-455. Medline

Shaner NC, Steinbach PA, Tsien RY (2005) A guide to choosing fluorescent proteins. Nat Methods 2:905-909. CrossRef Medline

Shen KZ, North RA (1993) Excitation of rat locus coeruleus neurons by adenosine $5^{\prime}$-triphosphate: ionic mechanism and receptor characterization. J Neurosci 13:894-899. Medline

Shigetomi E, Kato F (2004) Action potential-independent release of glutamate by $\mathrm{Ca}^{2+}$ entry through presynaptic $\mathrm{P} 2 \mathrm{X}$ receptors elicits postsynaptic firing in the brainstem autonomic network. J Neurosci 24:3125-3135. CrossRef Medline

Sim JA, Chaumont S, Jo J, Ulmann L, Young MT, Cho K, Buell G, North RA, Rassendren F (2006) Altered hippocampal synaptic potentiation in P2X4 knock-out mice. J Neurosci 26:9006-9009. CrossRef Medline

Sinchak K, Dewing P, Ponce L, Gomez L, Christensen A, Berger M, Micevych P (2013) Modulation of the arcuate nucleus-medial preoptic nucleus lordosis regulating circuit: a role for GABAB receptors. Horm Behav 64: 136-143. CrossRef Medline

Soto F, Garcia-Guzman M, Gomez-Hernandez JM, Hollmann M, Karschin

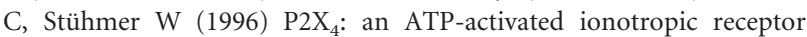
cloned from rat brain. Proc Natl Acad Sci U S A 93:3684-3688. CrossRef Medline

Steculorum SM, Paeger L, Bremser S, Evers N, Hinze Y, Idzko M, Kloppenburg P, Brüning JC (2015) Hypothalamic UDP increases in obesity and promotes feeding via P2Y6-dependent activation of AgRP neurons. Cell 162:1404-1417. CrossRef Medline

Sternson SM, Atasoy D (2014) Agouti-related protein neuron circuits that regulate appetite. Neuroendocrinology 100:95-102. CrossRef Medline

Stojilkovic SS (2009) Purinergic regulation of hypothalamopituitary functions. Trends Endocrinol Metab 20:460 -468. CrossRef Medline

Stokes L, Surprenant A (2009) Dynamic regulation of the P2X4 receptor in alveolar macrophages by phagocytosis and classical activation. Eur J Immunol 39:986-995. CrossRef Medline

Tóth K, McBain CJ (2000) Target-specific expression of pre- and postsynaptic mechanisms. J Physiol 525:41-51. CrossRef Medline

Toulme E, Khakh BS (2012) Imaging P2X4 receptor lateral mobility in microglia: regulation by calcium and p38 MAPK. J Biol Chem 287:1473414748. CrossRef Medline

Toulme E, Garcia A, Samways D, Egan TM, Carson MJ, Khakh BS (2010) $\mathrm{P} 2 \mathrm{X} 4$ receptors in activated C8-B4 cells of cerebellar microglial origin. J Gen Physiol 135:333-353. CrossRef Medline

Tsuda M, Shigemoto-Mogami Y, Koizumi S, Mizokoshi A, Kohsaka S, Salter MW, Inoue K (2003) P2X4 receptors induced in spinal microglia gate tactile allodynia after nerve injury. Nature 424:778-783. CrossRef Medline

Ulmann L, Hatcher JP, Hughes JP, Chaumont S, Green PJ, Conquet F, Buell GN, Reeve AJ, Chessell IP, Rassendren F (2008) Up-regulation of P2X4 receptors in spinal microglia after peripheral nerve injury mediates BDNF release and neuropathic pain. J Neurosci 28:11263-11268. CrossRef Medline

Ulmann L, Hirbec H, Rassendren F (2010) P2X4 receptors mediate PGE2 release by tissue-resident macrophages and initiate inflammatory pain. EMBO J 29:2290-2300. CrossRef Medline

Ulmann L, Levavasseur F, Avignone E, Peyroutou R, Hirbec H, Audinat E, Rassendren F (2013) Involvement of P2X4 receptors in hippocampal microglial activation after status epilepticus. Glia 61:1306-1319. CrossRef Medline

Wang CZ, Namba N, Gonoi T, Inagaki N, Seino S (1996) Cloning and pharmacological characterisation of a fourth $\mathrm{P} 2 \mathrm{X}$ receptor subtype widely expressed in brain and peripheral tissues including various endocrine tissues. Biochem Biophys Res Commun 220:196-202. CrossRef Medline

Wong AM, Abrams MC, Micevych PE (2015) $\beta$-Arrestin regulates estradiol membrane-initiated signaling in hypothalamic neurons. PLoS One 10: e0120530. CrossRef Medline

Wyatt LR, Godar SC, Khoja S, Jakowec MW, Alkana RL, Bortolato M, Davies DL (2013) Sociocommunicative and sensorimotor impairments in male P2X4-deficient mice. Neuropsychopharmacology 38:1993-2002. CrossRef Medline

Wyatt LR, Finn DA, Khoja S, Yardley MM, Asatryan L, Alkana RL, Davies DL (2014) Contribution of P2X4 receptors to ethanol intake in male C57BL/6 mice. Neurochem Res 39:1127-1139. CrossRef Medline

Xu J, Chai H, Ehinger K, Egan TM, Srinivasan R, Frick M, Khakh BS (2014) Imaging P2X4 receptor subcellular distribution, trafficking, and regulation using P2X4-pHluorin. J Gen Physiol 144:81-104. CrossRef Medline

Yang A, Sonin D, Jones L, Barry WH, Liang BT (2004) A beneficial role of cardiac P2X4 receptors in heart failure: rescue of the calsequestrin overexpression model of cardiomyopathy. Am J Physiol Heart Circ Physiol 287:H1096-H1103. CrossRef Medline

Yang L, Qi Y, Yang Y (2015) Astrocytes control food intake by inhibiting AGRP neuron activity via adenosine A1 receptors. Cell Rep 11:798-807. CrossRef Medline

Yang T, Shen JB, Yang R, Redden J, Dodge-Kafka K, Grady J, Jacobson KA, Liang BT (2014) Novel protective role of endogenous cardiac myocyte P2X4 receptors in heart failure. Circ Heart Fail 7:510-518. CrossRef Medline

Yang XW, Gong S (2005) An overview on the generation of BAC transgenic mice for neuroscience research. Curr Protoc Neurosci 5:20. CrossRef Medline

Yang XW, Model P, Heintz N (1997) Homologous recombination based modification in Escherichia coli and germline transmission in transgenic mice of a bacterial artificial chromosome. Nat Biotechnol 15:859-865. CrossRef Medline

Yardley MM, Wyatt L, Khoja S, Asatryan L, Ramaker MJ, Finn DA, Alkana RL, Huynh N, Louie SG, Petasis NA, Bortolato M, Davies DL (2012) Ivermectin reduces alcohol intake and preference in mice. Neuropharmacology 63:190-201. CrossRef Medline

Zemková $\mathrm{H}$, Tvrdonova $\mathrm{V}$, Bhattacharya A, Jindrichova M (2014) Allosteric modulation of ligand gated ion channels by ivermectin. Physiol Res 63 [Suppl 1]:S215-S224. 